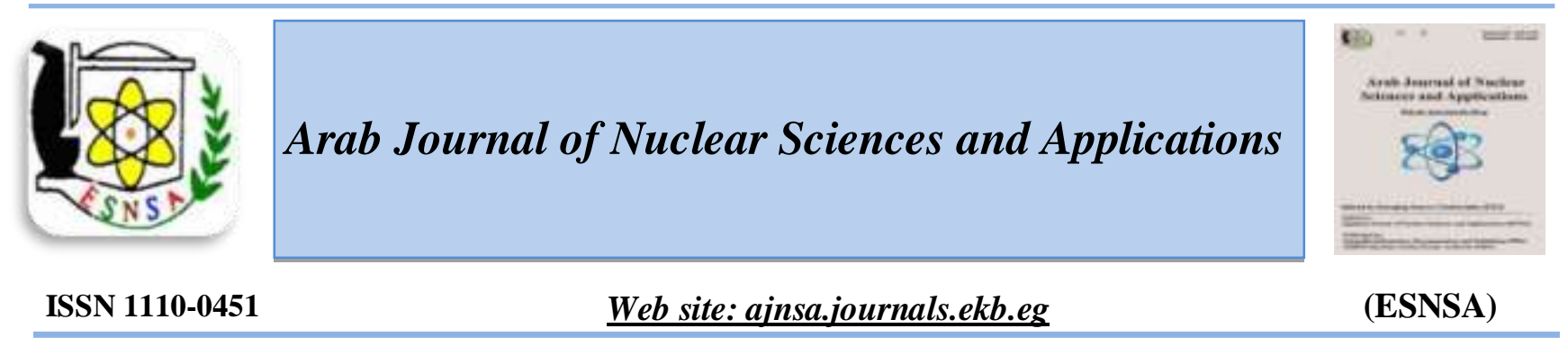

\title{
The Zug El Bohar Hydrothermal Uranium-Base Metal Deposits, Southwest El Quseir, Red Sea Coast, Egypt
}

\author{
Soliman Abu Elatta A. Mahmoud, Nariman M. Mosleh and Gehad M. R. Mansour \\ Nuclear Materials Authority
}

\begin{abstract}
Received 13rd May The Zug El Bohar area belongs to the Red Sea coastal plain of Egypt. Lithostratigraphically, this area is 2018 represented by a section of Late Cretaceous-Late Miocene sedimentary rocks and it is affected by both a Accepted $2^{\text {th }}$ July 2018 WNW-ESE sinistral strike-slip fault and a NNW-SSE shear zone. The deposits in the NNW-SSE shear zone were the subject of mineralogical and geochemical studies in order to elucidate the importance of these sediments for hosting valuable minerals. The geochemical study indicated that the shear zone has an abnormal concentration of $U$ as well as high concentrations of $\mathrm{Mo}, \mathrm{Pb}$, and $\mathrm{Zn}$ and As. Whereas the mineralogical study has not been detected any uranium minerals, whereas minerals such as wulfenite (PbMoO4), zaccagnaite $\left[\mathrm{Zn}_{4} \mathrm{Al}_{2}\left(\mathrm{CO}_{3}\right)(\mathrm{OH})_{12} .3 \mathrm{H}_{2} \mathrm{O}\right]$ and baileychlore $\left[\left(\mathrm{Zn}, \mathrm{Fe}^{2+}, \mathrm{Al}, \mathrm{Mg}\right)_{6}(\mathrm{Si}\right.$, $\left.\mathrm{Al})_{4} \mathrm{O}_{10}(\mathrm{OH})_{8}\right]$, mimetite $\left[\mathrm{Pb}_{5}\left(\mathrm{AsO}_{4}\right)_{3} \mathrm{Cl}\right]$, calcian mimetite, arsenatian vanadinite $\left[\mathrm{Pb}_{5}(\mathrm{~V}, \mathrm{As}) \mathrm{O}_{4} \mathrm{Cl}\right]$, Galena $(\mathrm{PbS})$ and zinnwaldite $\left[\mathrm{KLiFeAl}\left(\mathrm{AlSi}_{3}\right) \mathrm{O}_{10}(\mathrm{OH}, \mathrm{F})_{2}\right]$, celestite $\left(\mathrm{SrSO}_{4}\right)$ were identified. The deposits of the shear zone were formed due to a moderately oxidized saline fluid that led to precipitate minerals with a change in $\mathrm{pH}$ and temperature. The presence of $\mathrm{CaCO}_{3}$ and sulfate in the shear played an important role in decreasing the adsorption of $U$ on ferrihydrite and the disequilibrium with its daughters as well as the precipitation of $\mathrm{Mo}, \mathrm{Pb}, \mathrm{Zn}, \mathrm{As}$ and $\mathrm{REE}$ from the mixed solution.
\end{abstract}

Keywords: Zug El Bohar, El Quseir, Red Sea coastal plain, Shear zone, Disequilibrium and hydrothermal solution

\section{Introduction}

The Zug El Bohar studied area (Southwest El Quseir, Red Sea coastal plain, Egypt (Figure.1) is covered by a sequence of Late Cretaceous to Late Miocene sedimentary rocks (Figure. 2). The Zug El Bohar Phanerozoic sedimentary section is characterized by Nubian sandstones, El Quseir variegated shale (Quseir Formation), the Duwi Formation, the El Rusas Formation and the Abu Dabab Formation. The Zug El Bohar area has a similar climate to the Red Sea coastal plain between Safaga and El Quseir towns, in which the arid climate conditions are prevailing and the annual temperature ranges between 30 and $15^{\circ} \mathrm{C}$ in winter and between 46 and $35^{\circ} \mathrm{C}$ in summer [1]. Additionally, the night temperature sometimes drops to less than $10^{\circ} \mathrm{C}$ in winter. Rainfall precipitation is rare and usually takes place once every several years in the form of a torrent during a short time. Accordingly, terrace deposits are formed in the wadies whereas sediment reworking rates are low. The $U$ and other associated mineral deposits are found in the oxidized Phanerozoic sediments overlying a reduced basement complex and are located in the NNW-SSE shear zone. These deposits may have originated from invokes fluid originating from the emplaced younger igneous rocks (may be have a middle Miocene age as Wadi Wizr basalt that lies to the south of study area [2]) that are hidden under the sedimentary sequence, flowing upward and along the NNWSSE shear zone to precipitate $U$ and other redoxsensitive elements by reaction with the surrounded

Corresponding author: dr.soliman72@yahoo.com

DOI: 10.21608/ajnsa.2018.3801.1091

(C) Scientific Information, Documentation and Publishing Office (SIDPO)-EAEA 
rocks of this shear zone. The precipitation of minerals occurred by mixing with reduced basement-derived fluids and/or a reaction with an oxidized groundwater and materials within the surrounded Phanerozoic sedimentary sequence as many previous studies that consider the lead-zinc deposits along the Red Sea coast to be of hydrothermal origin $[3,4,5,6,7,8]$.
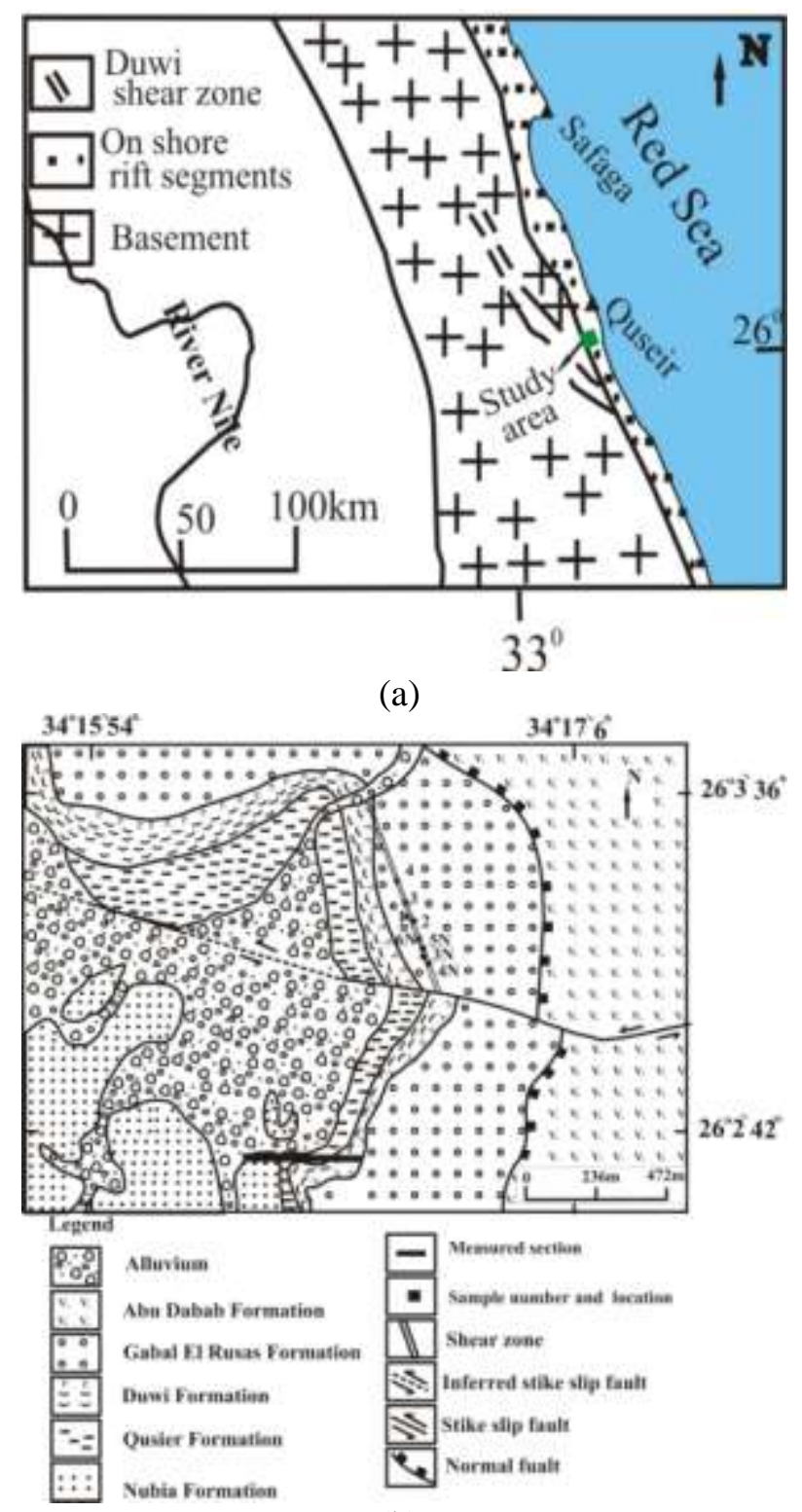

(b)

Figure (1): Location map (a) and a geologic map (b) of the study area (mostly modified after $[6,7,8])$

This study describes the Zug El Bohar U and other mineral deposits that occurred in the NNW-SSE shear zone and focuses on gaining a better understanding of its genesis based on geological and geochemical observations. This includes geologic mapping, mineral genesis, the physiochemical conditions that are prevailing during uranium transport, and the likely mechanisms of $\mathrm{U}, \mathrm{Mo}, \mathrm{Zn}, \mathrm{Pb}$ and As precipitation to quantify the effect of fluid mixing and reduction at the Zug El Bohar shear zone.

\section{Geologic setting}

The Late Cretaceous-Late Miocene sedimentary sequence (Figure. 2) in the study area, according to the light of the Red Sea tectonics, can be divided into:

(a) The pre-rift stage from the Cenomanian to the Maastrichtian (including Nubian sandstones, Quseir variegated shale and Duwi Formation)

(b) The post-rift stage from Middle to Late Miocene (Gabal El Rusas and Abu Dabab formations).

Nubian sandstones are located in the southwest of the study area. They are considered to be a Late Cretaceous [9] and [10] but it is considered to be an Early-Late Cretaceous in the Northern Red Sea (Quseir area, Gebel Duwi [11]). Furthermore, the Nubia Formation was subdivided into three lithologically distinct members within the El Quseir area [12] with the middle and upper member that are only the subject of the study area. Consequently, they may have the late Cretaceous age, where this formation is graded upward to fine sand and silt member forms the shales of the Quseir variegated shale, which is exposed in stratigraphic sequence at the east and the north of the mapped area. Quseir variegated shale separates between the underlying Nubian sandstones and the overlying Duwi Formation. The Quseir variegated shale is considered to be Senonian [13]. The thickness of the Quseir variegated shale in the mapped area is 55 to $65 \mathrm{~m}$. The Duwi Formation age is Campanian to Maastrichtian [14]. The thickness of the formation in the Quseir area is 55 to $57 \mathrm{~m}$. The Duwi Formation consists of alternating beds of marls, chert, shales, oyster limestone, siliceous limestone, enclosing a number of phosphate beds (Figure. 3a). The thickness of the formation in the study area ranges from 14 to19 $\mathrm{m}$. 


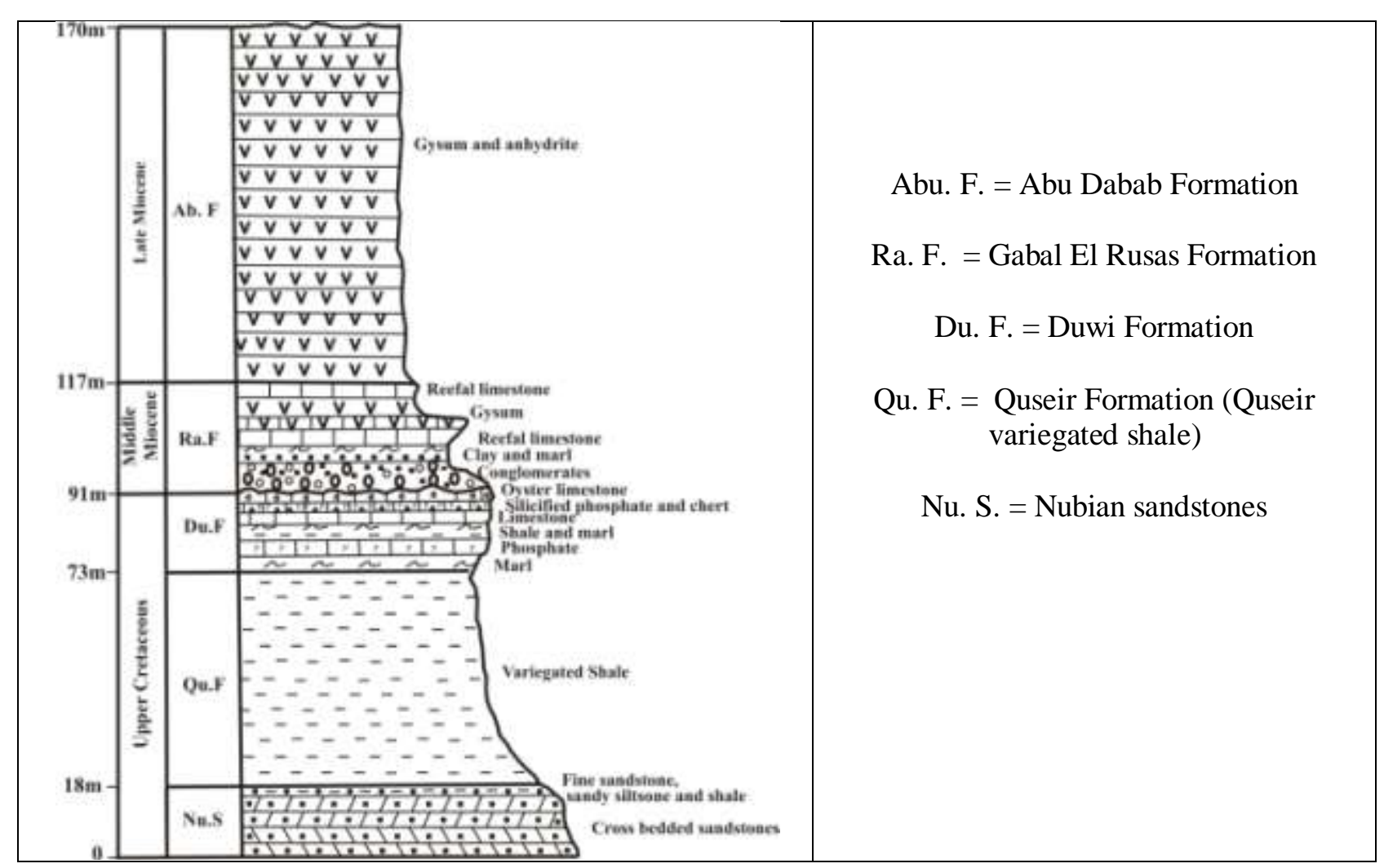

Figure (2): Platform sediments of the studied area (mostly modified after [12])

On the other hand, the pre-rift stratigraphic sequence that is exposed at the east and the north of study area is disconformably overlies by Gabal El Rusas formation (Middle Miocene [15]). This formation is overlaid by Abu Dabab Formation (Late Miocene) in the east of the study area. Gabal El Rusas Formation in the study area is represented by conglomerates, gritstone, calcareous sandstones, clay minerals, marl, gypsiferous and reefal limestone. The thickness and lithology of the Gabal El Rusas formation are extremely variable, due to a combination of irregular original depositional topography, synsedimentary tectonic activity [12]. Within the study area the average thickness of the formation is about of $24 \mathrm{~m}$.

The exposed stratigraphic sequence on the eastern side of the study area is crosscut by the WNWESE sinistral strike-slip fault, in addition to the NNW-SSE shear zone (Figure.1). This shear zone dips toward the WSW by an angle of about $65^{\circ}$. The shear zone (Figure. $3 b$ ) is variable in its width $(15-20 \mathrm{~m})$ and is characterized by different colors (Figure. 3c), ferrugination and breccias (Figure. $3 \mathrm{~d})$, in addition to a fault gouge in the uppermost part of it.

\section{Laboratory methods}

A total of eight representative samples from the southern side of the shear zone were chosen from the shear zone. These samples were crushed to a 60 mesh size. Two hundred grams of each sample were placed in plastic vessels, $10 \mathrm{~cm}$ diameter with a total capacity of $300 \mathrm{~cm}^{3}$. The vessels were sealed for 30 days to allow equilibrium and then measured by HPGe $\gamma$-ray detector model (GMX60P4), n-type crystal, from EG \& GORTEC. This detector has a resolution (FWHM) of $1.9 \mathrm{keV}$ for the $1332 \mathrm{keV}$ gamma-ray line of ${ }^{60} \mathrm{Co}$ and a relative efficiency of about $60 \%$ from NaI. The system was calibrated for energy to display gamma photo peaks between 30 and 3000 $\mathrm{keV}$ at laboratories of Nuclear Materials Authority.

After measuring each sealed sample, it was divided into two parts; one part was taken to carry out the mineralogical investigation of the heavy minerals using environmental scanning electron microscopy coupled with energy dispersive spectroscopy ESEM/EDX at laboratories of Nuclear Materials Authority and, the other part was ground again to a 200 mesh size for chemical analyses at the laboratories of Acme Labs., Canada using ICPOES and ICP-MS. 


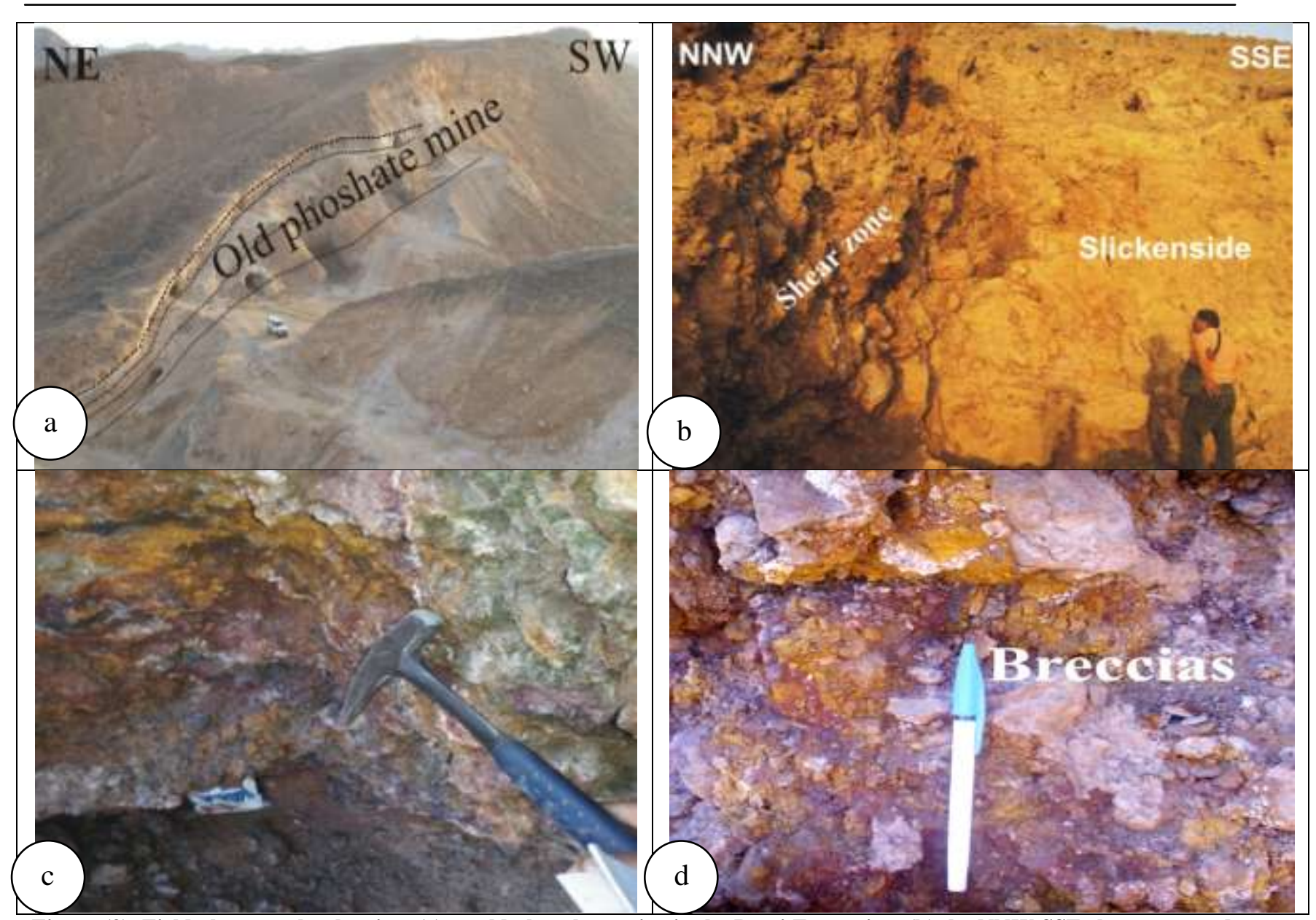

Figure (3): Field photographs showing, (a) an old phosphate mine in the Duwi Formation, (b) the NNW-SSE shear zone and its slickenside, (c) different colors of the shear zone, and (d) the shear zone breccias. Note, dashed lines in (a) are boundaries of phosphate beds

After measuring each sealed sample, it was divided into two parts; one part was taken to carry out the mineralogical investigation of the heavy minerals using environmental scanning electron microscopy coupled with energy dispersive spectroscopy ESEM/EDX at laboratories of Nuclear Materials Authority and, the other part was ground again to a 200 mesh size for chemical analyses at the laboratories of Acme Labs., Canada using ICPOES and ICP-MS.

\section{Mineralogy of the shear zone}

The polymetal mineralization that exists in the shear zone is probably due to the chemical activity of the surrounded lithology with the U-Mo-Pb-ZnAs- bearing hydrothermal solutions. This poly mineralization in the oxidation zone is marked with hematization and limonitization (Figures. 3bd) as well as kaolinite (Figure. 4a), gibbsite (Figure. 4b) and manganese oxides (Figure. 4c). The kaolin may be formed directly from hydrothermal solutions, with the effect of sulphurous, carbon dioxide solutions on aluminosilicate rocks (especially shale and clay minerals that are found in the ambient rocks of the shear zone) [16]. The followings display the minerals that were identified in the shear zone.

\section{a-Nickel oxi-hydroxide $\mathrm{NiO}(\mathrm{OH})$}

It occurs in a black solid state and was examined using the ESEM which mainly shows the presence of the concentration of $\mathrm{Ni}$ as well as traces of $\mathrm{Fe}$ and Si (Figure. 4d).

\section{$b$-Wulfenite $\mathrm{PbMoO}_{4}$}

Both wulfenite and powellite are secondary molybdenum minerals. Wulfenite mineral occurs as yellow and orange tabular crystals (Figures.5ab). Examination of the wulfenite crystals by the ESEM revealed that it is mainly composed of $\mathrm{Pb}$, $\mathrm{Mo}$ and $\mathrm{O}$ with impurities of $\mathrm{Fe}$ and $\mathrm{Zn}$ in some of them (Figure.5c) and calcium in the other (Figure.5d). The presence of $\mathrm{Ca}$ is because wulfenite crystals are structurally similar to 
powellite crystals and extensive solid solution relations exist between them [17]. This fact was proved in this study, where it was found that $\mathrm{Ca}$ increased in a one part side of the wulfenite crystal which would give a composition intermediate between wulfenite and powellite $\left(\mathrm{CaMoO}_{4}\right)$ see Figure.(5e). Wulfenite mineral is the main source for the molybdenum deposits in the study area that was formed mainly in an oxygen-rich environment and conditions of low temperature and low pressure [18]. The molybdenum concentrations in the form of the $\mathrm{HMoO}_{4}(\mathrm{sol}$.) complex are predicted only in highly alkaline solutions. An increase in acidity as a result of the temperature decrease is considered as an additional factor favouring molybdenite crystallization and preventing copper deposition [19].

\section{c-Zaccagnaite $\left(\mathrm{Zn}_{4} \mathrm{Al}_{2}\left(\mathrm{CO}_{3}\right)(\mathrm{OH})_{12} \cdot 3 \mathrm{H}_{2} \mathrm{O}\right)$}

Zaccagnaite occurs as white prismatic crystals of different sizes (Figure. 5f). These crystals are formed through hydrothermal alteration of sulfides and sulfosalts in the presence of aluminum-rich hydrothermal fluid [20]. The presence of crystals of zaccagnaite was confirmed by the ESEM (Figure. 5f). These crystals are composed essentially of $\mathrm{Zn}$ and $\mathrm{Al}, \mathrm{O}, \mathrm{C}$ and $\mathrm{H}$ ( $\mathrm{H}$ doesn't appear in this pattern because it is a light element) with an impurity of Si (Figure.5).

$$
\begin{aligned}
& \text { d-Baileychlore }\left[\left(\mathrm{Zn}, \quad \mathrm{Fe}^{2+}, \quad \mathrm{Al}, \quad \mathrm{Mg}\right)_{6}\right. \\
& \left.\mathrm{Al})_{4} \mathrm{O}_{10}(\mathrm{OH})_{8}\right]
\end{aligned}
$$

This mineral is a member of chlorite group, and it is found as pale green aggregates (Fig. $5 \mathrm{~g}$ ) and flakes. This mineral is $\mathrm{Zn}$-phyllosilicate that is formed in the presence of $\mathrm{Al}$ and $\mathrm{Si}$ under neutral conditions [21]. The presence of Baileychlore mineral was confirmed by the ESEM/EDX (Fig.5g), where is composed essentially of $\mathrm{Zn}, \mathrm{Fe}$, $\mathrm{Si}, \mathrm{Al}$, and $\mathrm{Mg}$, additionally to some impurities of $\mathrm{Ca}, \mathrm{Cl}$ and $\mathrm{S}$.

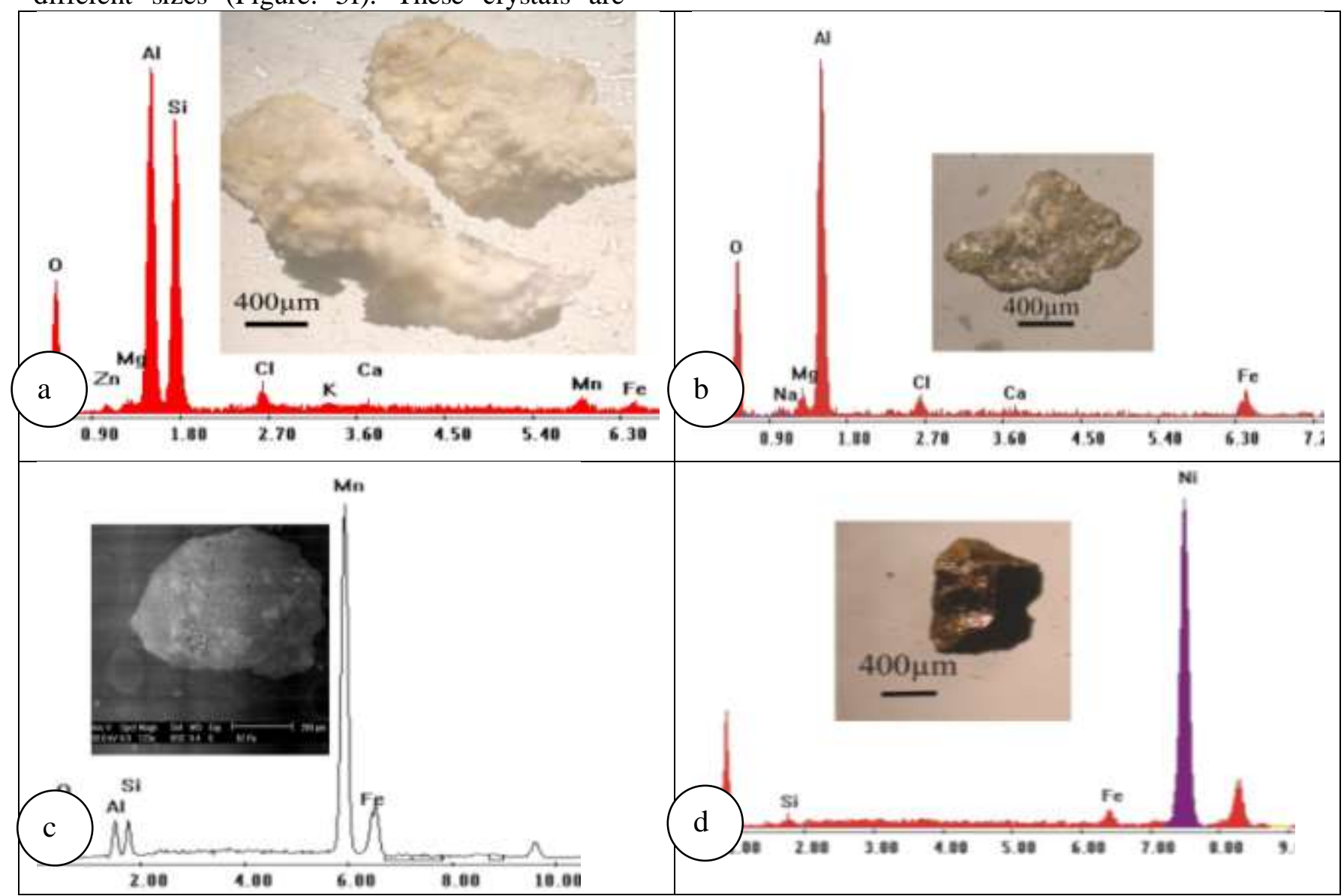

Figure (4): Photomicrographs and EDX patterns for (a) kaolinite mineral,(b) gibbsite,(c)manganese oxide and (d) nickel oxi-hydroxide 


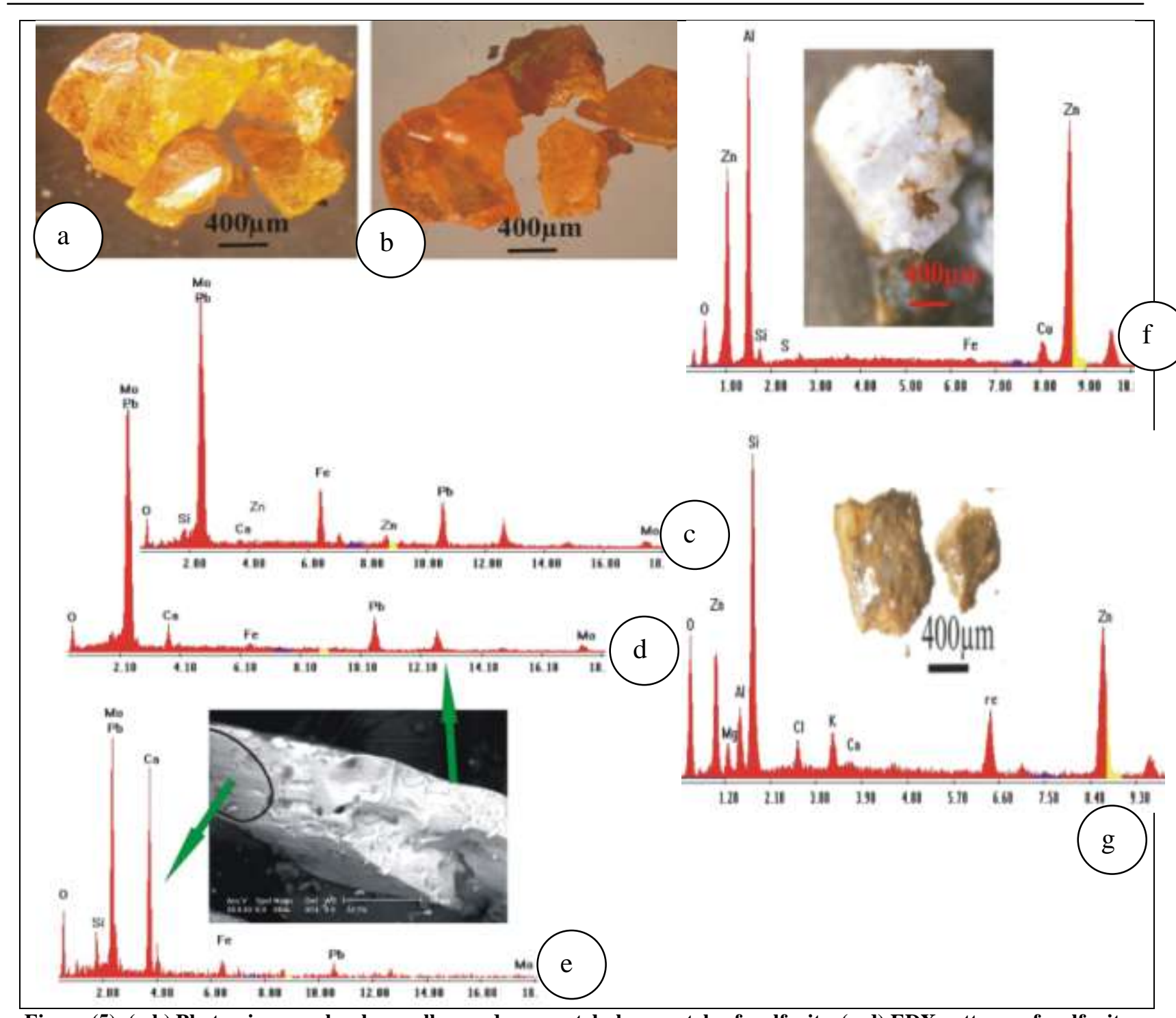

Figure (5): (a-b) Photomicrographs show yellow and orange tabular crystals of wulfenite, (c-d) EDX patterns of wulfenite show the difference in impurities, (e) ESEM/EDX of wulfenite crystal changed to a mixed crystal of wulfenite and powellite, and (f-g) Photomicrographs and EDX patterns of zaccagnaite and baileychlore respectively

f-Mimetite $\mathrm{Pb}_{5}\left(\mathrm{AsO}_{4}\right)_{3} \mathrm{Cl}$, calcian mimetite and arsenatian vanadinite $\mathrm{Pb}_{5}\left[(\mathrm{~V}, \mathrm{As}) \mathrm{O}_{4}\right]_{3} \mathrm{Cl}$

Mimetite occurs as yellow and brown crystals. These crystals occur as acicular crystals (Fig. 6a) and/ or rounded nodels immersed in iron oxides, whereas calcian mimetite is a variety of mimetite group where calcium substituting for the lead. Calcian mimetite mineral occurs as minute crystals immersed or rounded nodules (Fig. 6b) immersed in iron oxides also. Mimetite minerals are usually secondary minerals that were formed by the oxidation of arsenopyrite and galena [22]. Mimetite crystals were confirmed by the ESEM that showed essential elements as $\mathrm{Pb}, \mathrm{Cl}, \mathrm{O}$ and $\mathrm{As}$ (Fig. 6a), in addition to $\mathrm{Ca}$ in calcian mimetite (Fig. 6b). Arsenatian vanadinite occurs as prismatic crystals (Fig.6c) with brown to greybrown or creamy-yellow color. It is a mineral that has the intermediate composition between mimetite and vanadinite and composed essentially of $\mathrm{Pb}, \mathrm{V}, \mathrm{As}, \mathrm{Cl}$ and $\mathrm{O}$ (Fig. 6c).

\section{g- Galena PbS}

Galena is found as minute cubes immersed in iron oxides or gibbsite. These cubes have lead-grey color which is composed essentially from $\mathrm{Pb}$ and $\mathrm{S}$ (Fig. 6d), especially in sample 4.

\section{h-Muscovite $\quad \underline{K A} l_{2}\left(A l \underline{S i}_{3} \underline{O}_{10}\right)(\underline{F}, O \underline{H}) \quad$ and zinnwaldite $\underline{\mathrm{KLiFeAl}}\left(\mathrm{AlSi}_{3}\right) \underline{\mathrm{O}}_{10}(\mathrm{O} \underline{\mathrm{H}}, \underline{\mathrm{F}})_{2}$ Muscovite occurs as silvery-white flakes and its presence was confirmed by the ESEM (Fig.7a).}


Zinnwaldite occurs as tabular grey brown crystals (Fig.7b). It was identified by EDX and contains Si, $\mathrm{Al}, \mathrm{K}, \mathrm{Fe}, \mathrm{F}$ and $\mathrm{O}$ but Li doesn't appear in this pattern because it is a light element. Accordingly, the hydrothermal solution was enriched in $\mathrm{Al}, \mathrm{F}$ and $\mathrm{Cl}$.

\section{i- Celestite $\mathrm{SrSO}_{4}$}

Celestite mineral occurs in the shear zone as transparent to translucent well-shaped prismatic and tabular crystals, aggregates and tapering. Celestite crystals and aggregates show a wide range of colors from white, colorless, orange, orange-brown, light brown and yellow due to various impurities. Some crystals were examined by ESEM /EDX and are composed mainly of $\mathrm{Sr}, \mathrm{S}$ and $\mathrm{O}$ (Fig.7c).

\section{Geochemical aspects of shear zone}

Oxide and trace element concentrations

The samples were analyzed from the shear zone (Table 1) they indicated that this zone contains

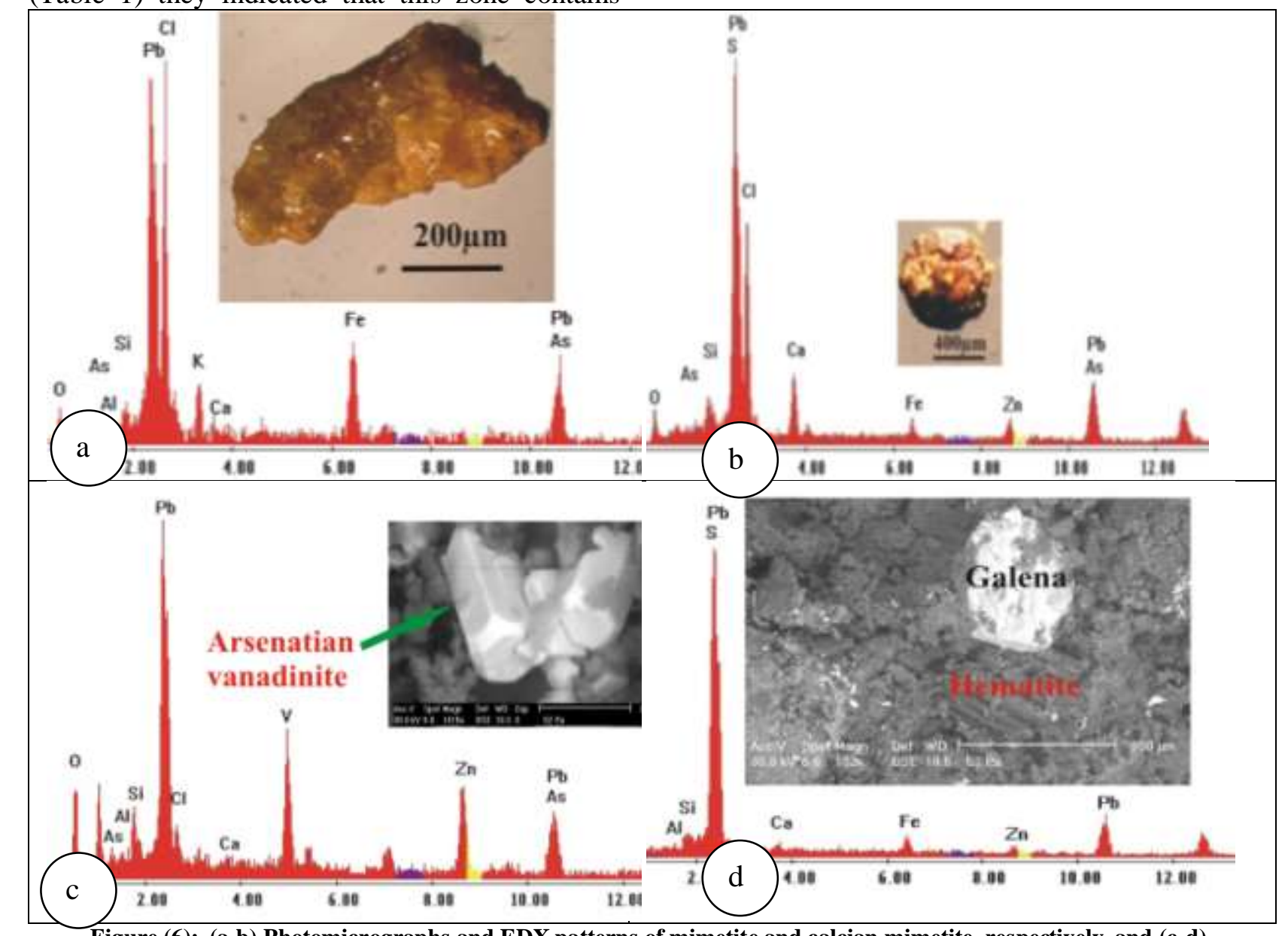

Figure (6): (a-b) Photomicrographs and EDX patterns of mimetite and calcian mimetite, respectively, and (c-d) ESEM/EDX of arsenatian vanadinite and galena respectively high concentrations of $\mathrm{FeO}_{\mathrm{t}}$ (total iron oxides) that range from $33.3 \%$ to $63.88 \mathrm{wt} \%$ and L.O.I ranging from 10.62 to $25.83 \mathrm{wt} \%$. However, other oxides such as $\mathrm{Al}_{2} \mathrm{O}_{3}$ ranges from 2.83 to11.51wt $\%, \mathrm{MgO}$ ranges from 0.7 to $1.53 \mathrm{wt} \%, \mathrm{CaO}$ ranges from 0.62 to $7.63 \mathrm{wt} \%, \mathrm{Na}_{2} \mathrm{O}$ ranges from 0.43 to $8.56 \mathrm{wt} \%$, $\mathrm{K}_{2} \mathrm{O}$ ranges from 0.05 to $0.42 \mathrm{wt} \%, \mathrm{TiO}_{2}$ ranges from 0.05 to $0.12 \mathrm{wt} \%, \mathrm{P}_{2} \mathrm{O}_{5}$ ranges from 0.03 to $0.09 \mathrm{wt} \%, \mathrm{MnO}$ ranges from 0.12 to1.2 wt $\%$ and $\mathrm{S}$ ranges from 0.62 to 4.31 . On the other hand, the trace elements show a significant difference in their concentrations, where $\mathrm{Li}$ ranges from 12.4 to160.4ppm, $\mathrm{Ba}$ ranges from $<1$ to $581 \mathrm{ppm}, \mathrm{V}$ ranges from 32 to122ppm, $\mathrm{Zn}$ ranges from 1236 to $21400 \mathrm{ppm}, \mathrm{Pb}$ ranges from 32.5to22400ppm, Ni ranges from 23 to $188.2 \mathrm{ppm}$, As ranges from 13.7 to $985.5 \mathrm{ppm}$, Sr ranges from 1809 to $>1 \%$, Mo ranges from 120.6 to $11000 \mathrm{ppm}$, $\mathrm{U}$ ranges from 41.4 to $187 \mathrm{ppm}$, Th ranges from 0.4 to $5.1 \mathrm{ppm}$ and finally $\mathrm{Ag}$ ranges from 0.2 to $0.8 \mathrm{ppm}$. 


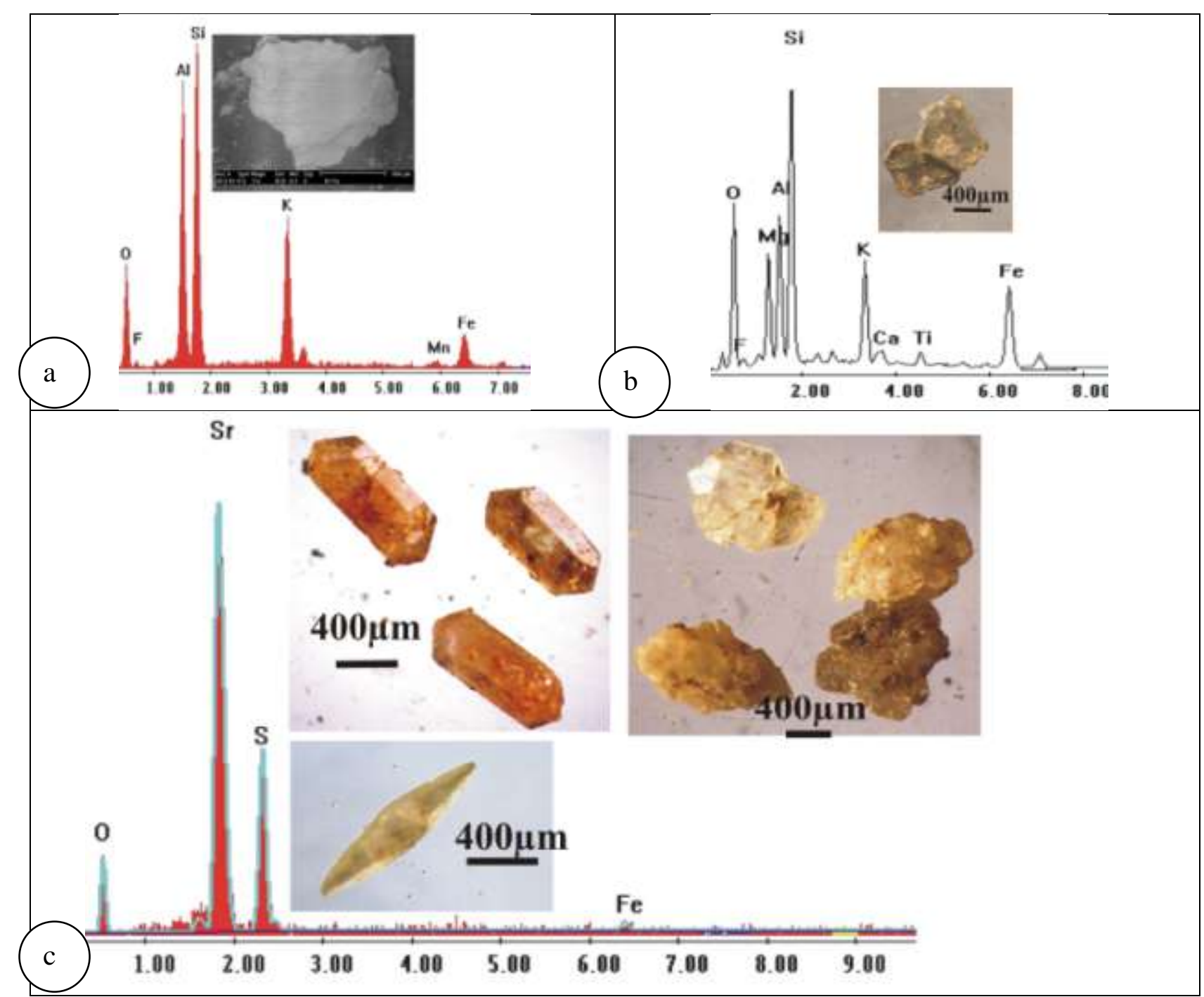

Figure (7): (a) ESEM/EDX of muscovite, (b) Photomicrograph and EDX pattern of zinnwaldite and (c) Photomicrographs and EDX pattern of celestite

The bulk geochemistry of the shear zone samples show an increase in uranium concentrations also with an increase in both $\mathrm{Al}_{2} \mathrm{O}_{3}$ (Fig. 8a) and $\mathrm{MnO}$ (Fig. 8b), contrary of $\mathrm{S} \%$ that show a strong negative correlation with an increasing uranium (Fig. 8c). Additionally, the $\mathrm{CaO}$, Mo and $\mathrm{V}$ show a sharp decrease with increasing uranium (Figs. 8df).

The most dramatic relationships are a weak positive between uranium and iron oxides (Fig. 8g) and a constant of $\mathrm{MgO}$ with increasing uranium (Fig. 8h). On the other hand, there is a sharp increase in $\mathrm{Mo}, \mathrm{Zn}$ and $\mathrm{Pb}$ with a sharp increase of $\mathrm{CaO}$ (Figs. 9a-c). Also, there is a sharp increase in As with a sharp increase of S\% (Fig. 9d).

\section{Rare earth elements}

The studied samples are characterized by low REE concentrations, where they ranged from 22.5 to $140.4 \mathrm{ppm}$ and the LREE predominate over the HREE elements except sample $(6 \mathrm{~N})$ in which the LREE is approximately equal to the HREE. The low concentrations of the REE may be because REE move in the low-temperature hydrothermal solutions as sulfate complex or free ions so that the small ionic radius of $\mathrm{Fe}$ has very little influence on them. On the other hand, the presence of low REE concentrations suggested their probable adsorption onto surfaces of clay minerals. The REE profiles in the hydrothermal deposits are usually used for the discussion of the prevailing physicochemical conditions (e.g. pH, alkalinity, temperature) during their formation. 
Table (1): Chemical composition of major elements (\%), traces and REEs (ppm) of the mineralized samples of the shear zone

\begin{tabular}{|c|c|c|c|c|c|c|c|c|}
\hline \multicolumn{9}{|c|}{ The shear zone samples } \\
\hline $\begin{array}{l}\text { S. No. } \\
\text { Oxide }\end{array}$ & 1 & 2 & 3 & 4 & $3 \mathbf{N}$ & $4 N$ & $5 \mathrm{~N}$ & $6 \mathrm{~N}$ \\
\hline $\mathrm{SiO}_{2}$ & 21.46 & 10.53 & 18.83 & 15.38 & 15.57 & 24.03 & 17.35 & 21.38 \\
\hline $\mathbf{A l}_{2} \mathbf{O}_{3}$ & 10.56 & 4.76 & 2.9 & 2.63 & 2.83 & 11.51 & 6.65 & 6.18 \\
\hline $\mathrm{TiO}_{2}$ & 0.12 & 0.06 & 0.05 & 0.11 & 0.05 & 0.1 & 0.09 & 0.09 \\
\hline FeOt & 34.92 & 63.88 & 55.00 & 33.30 & 54.75 & 45.99 & 53.77 & 46.02 \\
\hline MgO & 1.24 & 0.7 & 0.9 & 1.53 & 0.9 & 1.16 & 1.23 & 0.91 \\
\hline $\mathrm{CaO}$ & 0.62 & 0.63 & 0.9 & 7.63 & 0.9 & 0.34 & 1.08 & 3.67 \\
\hline MnO & 1.1 & 0.75 & 0.58 & 0.12 & 0.58 & 1.03 & 1.2 & 0.47 \\
\hline $\mathrm{Na}_{2} \mathrm{O}$ & 8.56 & 1.99 & 0.43 & 2.73 & 0.43 & 2.41 & 1.24 & 2.32 \\
\hline $\mathrm{K}_{2} \mathrm{O}$ & 0.39 & 0.18 & 0.05 & 0.22 & 0.06 & 0.42 & 0.29 & 0.29 \\
\hline $\mathbf{P}_{2} \mathbf{O}_{5}$ & 0.05 & 0.03 & 0.06 & 0.09 & 0.06 & 0.05 & 0.05 & 0.06 \\
\hline $\mathbf{S}$ & 0.59 & 0.62 & 2.59 & 4.31 & 2.31 & 1.52 & 1.33 & 3.55 \\
\hline L.O.I & 19.24 & 14.43 & 15.88 & 25.83 & 18.22 & 10.62 & 14.14 & 13.39 \\
\hline \multicolumn{9}{|c|}{ Trace elements } \\
\hline $\mathbf{L i}$ & 160.4 & 28.3 & 20 & 12.4 & 18.9 & 72.6 & 95 & 34 \\
\hline Ba & 340 & 204 & $<1$ & 28 & 349 & 349 & 581 & $<1$ \\
\hline Co & 16.3 & 17 & 6.5 & 4.8 & 6.6 & 28.2 & 2.6 & 8.9 \\
\hline V & 58 & 32 & 47 & 122 & 46 & 39 & 38 & 38 \\
\hline $\mathbf{Z n}$ & 4644.1 & 4472.5 & 1240.6 & 21400 & 1236 & 2379.1 & 3624.4 & 1250.7 \\
\hline $\mathbf{P b}$ & 46 & 32.5 & 133.5 & 22400 & 129.4 & 59.7 & 52 & 36.5 \\
\hline As & 21 & 21.7 & 30.6 & 985.5 & 28.7 & 13.7 & 32.3 & 25.4 \\
\hline Tl & 57.1 & 50.84 & 45.95 & 2.04 & 76.27 & 88.34 & 88.34 & 12.43 \\
\hline Se & 8.1 & 19 & 55 & 2.7 & 57.8 & 39.1 & 18.7 & 14.9 \\
\hline $\mathbf{N i}$ & 188.2 & 68.8 & 37.8 & 23 & 36.2 & 104.4 & 143.9 & 60 \\
\hline Cd & 18 & 2.5 & 2.4 & 15 & 3.4 & 2.5 & 5 & 1.5 \\
\hline Ag & 0.8 & 0.2 & 0.3 & 0.3 & 0.4 & 0.8 & 0.5 & 0.2 \\
\hline Mo & 264.3 & 312.4 & 218.5 & 11000 & 218.2 & 161.8 & 277.1 & 120.6 \\
\hline $\mathbf{S r}$ & 5421 & 9007 & $>1 \%$ & 1809 & $>1 \%$ & $>1 \%$ & $>1 \%$ & $>1 \%$ \\
\hline Th & 0.5 & 5.1 & 0.5 & 1.8 & 0.4 & 1.7 & 1.1 & 1.1 \\
\hline $\mathbf{U}$ & 178 & 187 & 63.5 & 41.4 & 60.5 & 133 & 134 & 78 \\
\hline \multicolumn{9}{|l|}{ REEs } \\
\hline La & 9.1 & 4.6 & 2.7 & 5.1 & 2.5 & 8.8 & 10.3 & 6.3 \\
\hline $\mathrm{Ce}$ & 36.6 & 10.72 & 8.09 & 35.12 & 7.43 & 14.23 & 25.26 & 13.74 \\
\hline Pr & 6.1 & 1.4 & 1.1 & 2 & 1 & 1.5 & 3.1 & 2.1 \\
\hline Nd & 27 & 4.9 & 4.3 & 7.7 & 3.6 & 5.2 & 12.2 & 7.8 \\
\hline Sm & 6.9 & 1.2 & 0.9 & 1.8 & 1 & 1 & 2.7 & 1.7 \\
\hline Eu & 1.9 & 0.3 & 0.2 & 0.3 & 0.2 & 0.2 & 0.7 & 0.4 \\
\hline Gd & 7.3 & 1.2 & 0.7 & 1.3 & 0.6 & 1.2 & 3.4 & 1.7 \\
\hline $\mathbf{T b}$ & 1.1 & $<0.1$ & $<0.1$ & $<0.1$ & $<0.1$ & $<0.1$ & 0.2 & 0.2 \\
\hline Dy & 6.5 & 1.2 & 0.8 & 1.6 & 0.7 & 1.1 & 2.3 & 3.3 \\
\hline Ho & 1.5 & 0.3 & 0.2 & 0.3 & 0.1 & 0.2 & 0.5 & 0.8 \\
\hline Er & 3.9 & 0.5 & 0.4 & 0.9 & 0.5 & 0.7 & 1.2 & 2 \\
\hline Tm & 0.6 & $<0.1$ & $<0.1$ & 0.1 & $<0.1$ & $<0.1$ & 0.2 & 0.4 \\
\hline $\mathbf{Y b}$ & 3.2 & 0.6 & 0.3 & 1 & 0.4 & 0.5 & 1.1 & 1.6 \\
\hline $\mathbf{L u}$ & 0.1 & $<0.1$ & $<0.1$ & 0.1 & $<0.1$ & 0.1 & 0.2 & 0.3 \\
\hline $\mathbf{Y}$ & 28.6 & 5.9 & 4.3 & 7.4 & 4.5 & 5.4 & 13.6 & 20.7 \\
\hline ¿REE & 140.4 & 32.82 & 23.99 & 64.72 & 22.53 & 40.13 & 76.96 & 63.04 \\
\hline इLREE & 87.6 & 23.12 & 17.29 & 52.02 & 15.74 & 30.93 & 45.26 & 32.04 \\
\hline इHREE & 52.8 & 9.7 & 6.7 & 12.7 & 6.8 & 9.2 & 22.7 & 31 \\
\hline $\mathbf{E u} / \mathbf{E u} *$ & $\mathbf{0 . 8 2}$ & 0.76 & 0.77 & 0.60 & 0.79 & 0.58 & 0.71 & 0.72 \\
\hline $\mathrm{Ce} / \mathrm{Ce}^{*}$ & 1.17 & 1.01 & 1.13 & 1.9 & 1.11 & 0.91 & 1.08 & 0.91 \\
\hline
\end{tabular}

$\mathrm{FeOt}=$ total iron, $\mathrm{HHREE}=$ including $\mathrm{Y}$ 


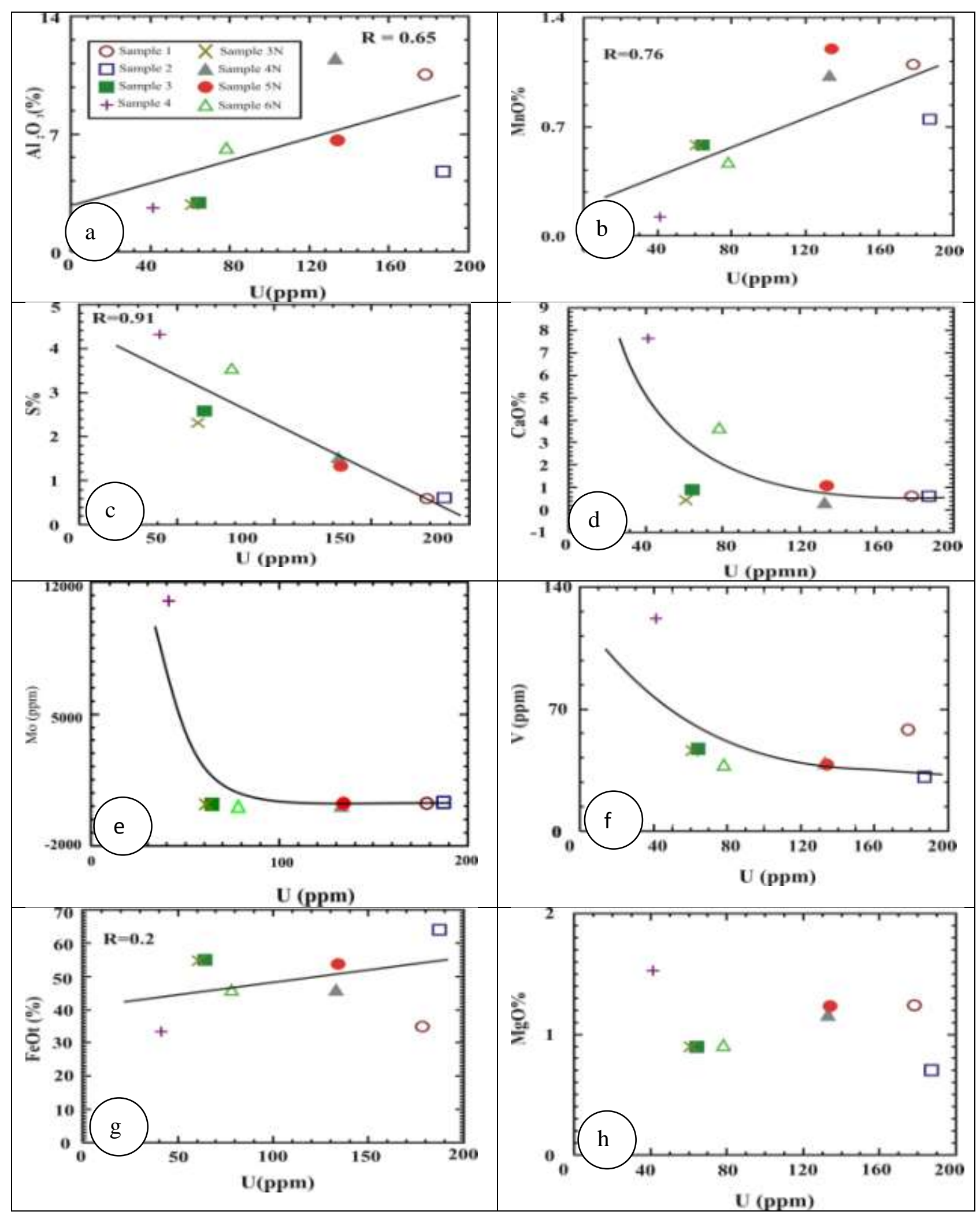

Figure (8): (a-h) Binary diagrams of $\mathrm{U}$ versus $\mathrm{Al}_{2} \mathrm{O}_{3}, \mathrm{MnO}, \mathrm{S} \%$, CaO, $\mathrm{Mo}, \mathrm{V}, \mathrm{FeOt}$ and $\mathrm{MgO}$ respectively 


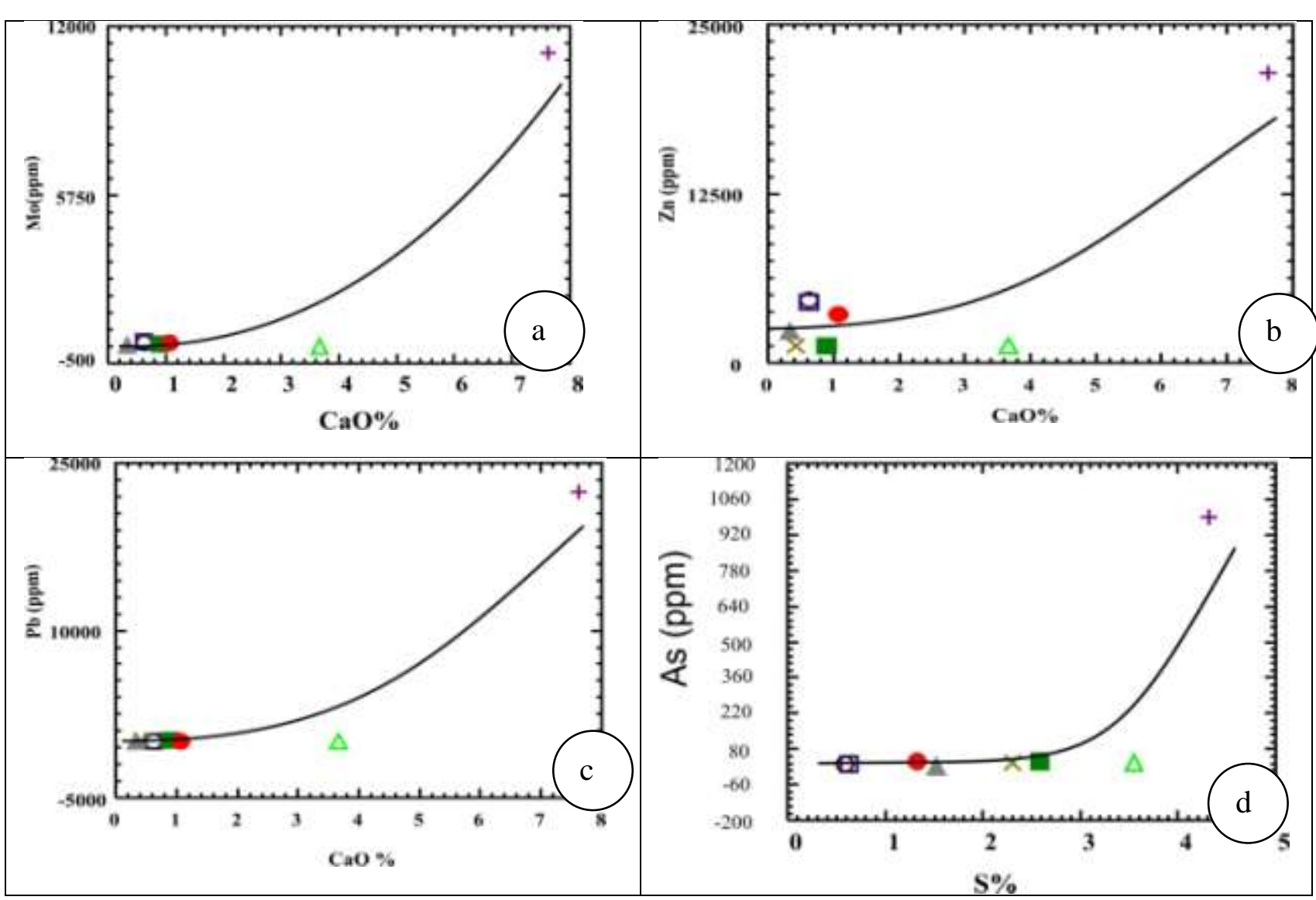

Figure (9): (a-c) Binary diagrams of $\mathrm{CaO}$ versus $\mathrm{Mo}, \mathrm{Zn}, \mathrm{Pb}$ respectively, while (d) is $\mathrm{S} \%$ versus As. Symbols as Fig. (8a)

The REE distribution is usually influenced by chemical crystallographic constraints, kinetics of crystallization, conditions (T-P), and the composition of the hydrothermal fluids [23]. The REE profiles of the studied samples (Fig.10) indicate moderate to weak negative Eu anomalies $\left(\mathrm{Eu} / \mathrm{Eu}^{*}=058-82\right.$, Table 1$)$ and depleted and strong negative $\mathrm{Tb}$ anomalies in all samples, contrary to positive $\mathrm{Gd}$ anomalies in all samples. Moreover, some samples show positive $\mathrm{Ce}$ anomalies $\left(\mathrm{Ce} / \mathrm{Ce}^{*}=0.91-1.89\right.$, Table 1$)$.

\section{Radiometric aspects of the shear zone}

It is worth noting that the uranium and thorium hold similar characteristics in their ionic radii which may illustrate why they both behave isochemically during the magmatic process [24]. However, hydrothermal process, $\mathrm{U}^{4+}$ gets oxidized easily in the shear zone to $\mathrm{U}^{6+}$ which is known to be soluble in groundwater, while Th doesn't, as it maintain insoluble in the oxidization zone. Hence, for the original concentration of $U$ in the rock, $T h$ can be used as a proxy [25]. A good indicator for the migration of uranium in the shear zone is the $\mathrm{U} / \mathrm{Th}$ ratio, whereas if the ratio $\mathrm{Th} / \mathrm{U}$ remains approximately constant in crust [26], so the migration of uranium has not occurred, but in the shear zone it ranges from 0.003 to 0.043 (Table 1), thus uranium has been migrated from its original source into the shear zone.

\section{Activity $\left(B q \mathrm{~kg}^{-1}\right)$ and activity ratios}

The results of the measurements of the specific activity $\left(\mathrm{Bqkg}^{-1}\right)$ of different radionuclides in the studied samples are presented in table (2). This table shows the activity concentration of ${ }^{238} \mathrm{U}$ ranging from $767 \pm 19.07 \mathrm{Bqkg}^{-1}$ to $4452.38 \pm 79.32$ $\mathrm{Bqkg}^{-1}$ which is higher than the recommended value which is documented as $35 \mathrm{Bqkg}^{-1}[28] .{ }^{235} \mathrm{U}$ is ranging between $45.11 \pm 1.86 \mathrm{Bqkg}^{-1}$ and $204.29 \pm 4.15 \mathrm{Bqkg}^{-1} .{ }^{232} \mathrm{Th}$ is ranging between $3.28 \pm 0.14$ and $5.89 \pm 0.76 \mathrm{Bqkg}^{-1}$ which is lower than the worldwide average which is documented at $30 \mathrm{Bqkg}-1$ [28]. ${ }^{226} \mathrm{Ra}$ is ranging between 745.28 $\pm 3.57 \mathrm{Bqkg}^{-1}$ and $3926.35 \pm 12.27 \mathrm{Bqkg}^{-1}$ which is higher than the recommended value which is documented at $35 \mathrm{Bqkg}^{-1}$ [28], but ${ }^{40} \mathrm{~K}$ is ranging from $17.5 \pm 0.76 \mathrm{Bqkg}^{-1}$ to $134.26 \pm 4.05$ $\mathrm{Bqkg}^{-1}$ which is lower than the worldwide average. 


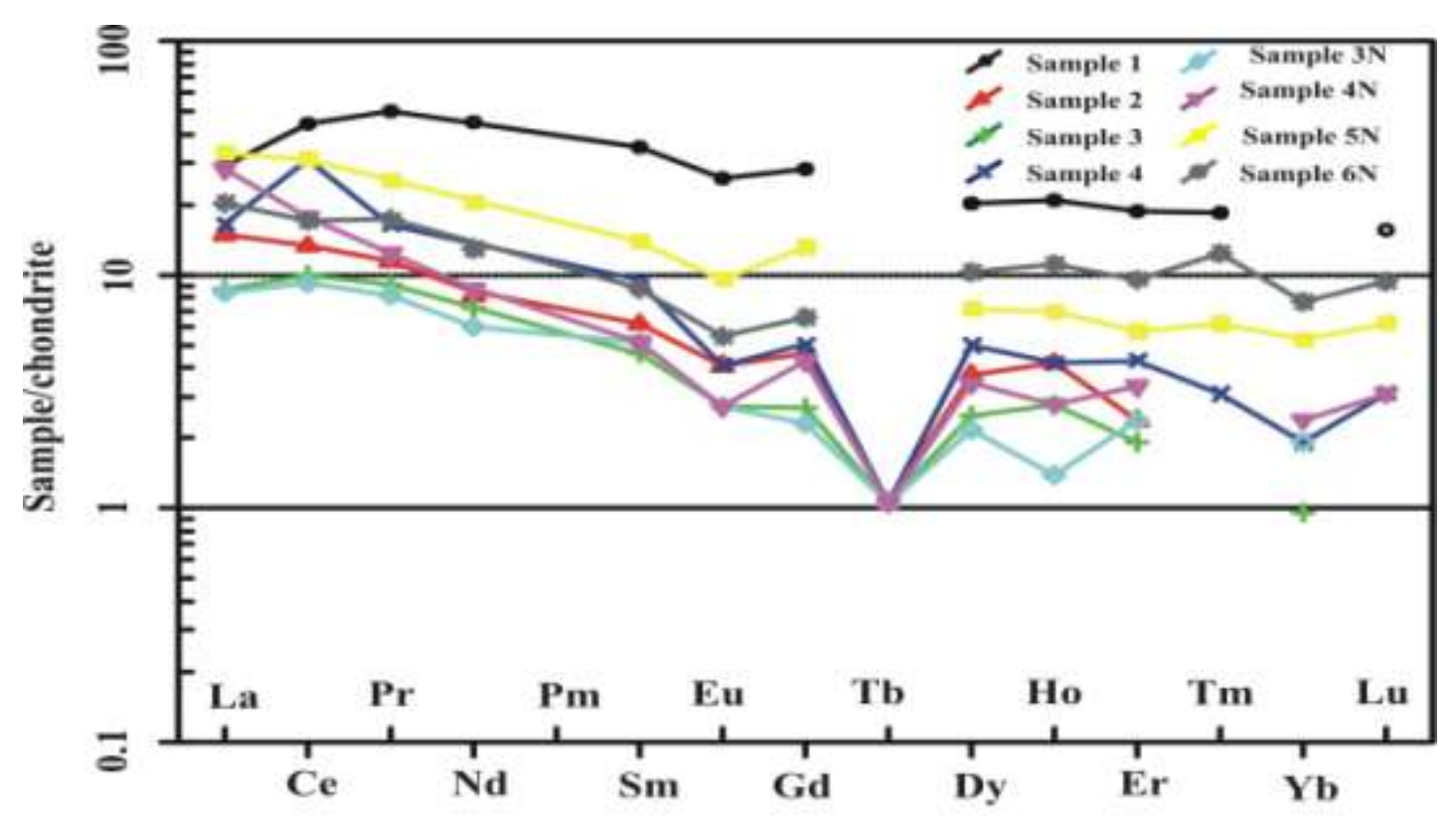

Figure (10): Profiles of REE of the shear zone samples (after [27])

Table (2): Specific activity $\left(\mathrm{Bq} \mathrm{kg}^{-1}\right)$ of some radionuclides of the mineralized samples of the shear zone

\begin{tabular}{|c|c|c|c|c|c|c|c|c|}
\hline \multicolumn{9}{|c|}{ Sample No } \\
\hline $234 \mathrm{Th}$ & $3880.88 \pm 19.45$ & $1711.27 \pm 13.04$ & $798.94 \pm 9.26$ & $2621.27 \pm 14.55$ & $323 \pm 4.19$ & $1035.87 \pm 8.3$ & $1738.8 \pm 12.16$ & $534.91 \pm 6.26$ \\
\hline${ }^{234 \mathrm{~m}} \mathrm{~Pa}$ & $4452.38 \pm 79.32$ & $2389.32 \pm 60.93$ & $1010.16 \pm 36.39$ & $2605.43 \pm 46.03$ & $767 \pm 19.07$ & $1481.77 \pm 25.15$ & $2681.12 \pm 47.46$ & $983.25 \pm 30.24$ \\
\hline${ }^{234} \mathbf{U}$ & $4139.86 \pm 71.21$ & $2137.18 \pm 563.43$ & $945.09 \pm 494.79$ & $2781.28 \pm 306.75$ & $758.72 \pm 169.94$ & $1265.69 \pm 469.6$ & $2357.55 \pm 409.2$ & $981.62 \pm 383.5$ \\
\hline $230 \mathrm{Th}$ & $3452.94 \pm 90.54$ & $1642.44 \pm 53.44$ & $1149.5 \pm 50.1$ & $2321.46 \pm 78.9$ & $304.43 \pm 18.15$ & $959.82 \pm 34.32$ & $1666.12 \pm 49.91$ & $585.71 \pm 26.78$ \\
\hline${ }^{226} \mathbf{R a}$ & $3926.35 \pm 12.27$ & $2794.26 \pm 9.9$ & $973.59 \pm 4.75$ & $2602.14 \pm 9.99$ & $745.28 \pm 3.57$ & $1889.86 \pm 6.93$ & $3140.55 \pm 10.04$ & $1029.4 \pm 5.25$ \\
\hline \multicolumn{9}{|c|}{ Thorium-series $\left({ }^{232} \mathrm{Th}\right)$} \\
\hline${ }^{228} \mathrm{Ac}$ & $3.94 \pm 1.4$ & -----士------ & $5.83 \pm 1.28$ & $4.63 \pm 0.49$ & $3.38 \pm 0.26$ & $6.14 \pm 0.5$ & $3.44 \pm 0.6$ & $4.15 \pm 0.57$ \\
\hline${ }^{208} \mathrm{Tl}$ & $3.26 \pm 0.15$ & $3.28 \pm 0.14$ & $5.94 \pm 0.23$ & $5.1 \pm 0.2$ & $3.2 \pm 0.11$ & $5.6 \pm 0.2$ & $3.39 \pm 0.15$ & $3.98 \pm 0.16$ \\
\hline Av. & $3.72 \pm 0.98$ & $3.28 \pm 0.14$ & $5.89 \pm 0.76$ & $4.87 \pm 0.35$ & $3.29 \pm 0.19$ & $5.87 \pm 0.35$ & $3.41 \pm 0.35$ & $4.06 \pm 0.35$ \\
\hline${ }^{235} \mathrm{U}$ & $204.29 \pm 4.15$ & $109.51 \pm 3.14$ & $46.39 \pm 2.57$ & $120.34 \pm 4.76$ & $34.9 \pm 1.34$ & $68.02 \pm 2.35$ & $123.99 \pm 2.53$ & $45.11 \pm 1.86$ \\
\hline
\end{tabular}

In closed geological systems the activity ratios (ARs) ${ }^{234} \mathrm{U} /{ }^{238} \mathrm{U},{ }^{230} \mathrm{Th} /{ }^{234} \mathrm{U},{ }^{230} \mathrm{Th} /{ }^{238} \mathrm{U}, \quad$ and ${ }^{226} \mathrm{Ra} /{ }^{238} \mathrm{U}$ all are equal to unity. Uranium-series disequilibrium can potentially provide an important tool for tracing the migration of uranium series radionuclides in the groundwater from different aquifer conditions and, thus, it has extensively been applied to the study of environmental, marine and earth sciences [29]. Briefly, two types of mechanisms produce variations in the $\mathrm{U}$-series nuclides. The first is when chemical or physical processes disturb parent and daughter element pairs (e.g., dissolution, adsorption, precipitation). The second is known as the $\alpha$-recoil effect. During the ejection of a particle, the daughter nuclide recoils in the opposite direction and moves within the host mineral. Because it may be ejected from the host mineral or because its crystallographic site is damaged, the parent daughter is more easily mobilized [30]. The following paragraphs demonstrate the activity ratios (Table 3 ) that were found in the studied samples of the shear zone:-

The ${ }^{234} \mathrm{U} /{ }^{238} \mathrm{U}$ ARs are varying from 0.85 to 1.07 . It is for the all samples are around unity with an average value 0.91 . This indicates a near secular 
equilibrium condition for this daughter-parent pair for this deposit.

The ${ }^{230} \mathrm{Th} /{ }^{238} \mathrm{U}$ ARs are varying from 0.4 to 1.14 . All samples are lower than unity with an average value 0.7 , except sample 3 (1.14). This display values out of equilibrium condition for this daughter-parent pair for this deposit. On other hand, the ${ }^{230} \mathrm{Th} /{ }^{234} \mathrm{UARs}$ are varying from 0.4 to 1.22. All samples are lower than unity with an average value 0.7 , except sample 3 is greater than unity equal 1.22. This indicates disequilibrium condition for this daughter-parent pair for this deposit. Furthermore, the activity ratios changed to ${ }^{234} \mathrm{U} /{ }^{238} \mathrm{U}<1$ and ${ }^{230} \mathrm{Th} /{ }^{234} \mathrm{U}<1$ in the most samples may be due to ${ }^{234} \mathrm{U}$ and ${ }^{238} \mathrm{U}$ have similar behavior by chemical weathering of minerals. But several authors have shown that this assumption is sometimes not verified in nature. The reason is known as the $\alpha$-recoil effect.

The binary diagram of ${ }^{230} \mathrm{Th} /{ }^{238} \mathrm{U}$ versus ${ }^{234} \mathrm{U} /{ }^{238} \mathrm{U}$ (Fig. 11), where the pathways of return to equilibrium for solid phases are shown for two cases: accumulation of $\mathrm{U}\left({ }^{230} \mathrm{Th} /{ }^{238} \mathrm{U}<1\right)$ and leaching of $\mathrm{U}\left({ }^{230} \mathrm{Th} /{ }^{238} \mathrm{U}>1[31,32]\right.$. This diagram indicates that most samples are presented in the forbidden zone whereas sample (4) is plotted in the accumulation zone and the sample (3) is plotted in the leaching zone. The forbidden region is a complex geochemical region where the systems can be identified as having suffered complicated U migration. A complex leaching and accumulation of uranium might take place for those samples $(1,2,4 \mathrm{~N}$ and $5 \mathrm{~N})$. The presence of data points in the forbidden zones may be a result of continuous and contrasting $U$ mobilization processes [33]. Depending on the relative rates of
$\mathrm{U}$ gains and losses and on the intensity of the $\mathrm{U}$ fractionation, it is possible to explain the data points present in the forbidden zone [30]. For the latter samples $(3 \mathrm{~N}$ and $6 \mathrm{~N})$, an initial uranium accumulation phase may have been followed by relatively recent uranium leaching.

Additionally, the activity ratios of ${ }^{226} \mathrm{Ra} /{ }^{238} \mathrm{U}$ vary from 0.88 to 1.28 , which indicates that all samples are close to equilibrium except ( 1 and $4 \mathrm{~N}$ ) samples are nearly closed ( 0.88 and 1.28 respectively). The ${ }^{226} \mathrm{Ra} /{ }^{238} \mathrm{U}$ is also a good indicator for alteration processes [34] and migration of either ${ }^{238} \mathrm{U}$ or ${ }^{226} \mathrm{Ra}$ according to the $\mathrm{pH}$ prevailed.

The activity ratios of ${ }^{226} \mathrm{Ra} /{ }^{230} \mathrm{Th}$ vary from 0.85 to 2.45. Two samples ( 1 and 4) were close to equilibrium, but the other samples are out of equilibrium. These ratios are greater than unity except sample 3 which is lower than unity. ${ }^{226} \mathrm{Ra}$ redistribution is caused by an instantaneous chemical process, which must have occurred during the last 8000 years, which is the time needed to reach radioactive equilibrium between ${ }^{226} \mathrm{Ra}$ and ${ }^{230} \mathrm{Th}$. A more continuous redistribution process could have started earlier, but should still have been active during the last 8000 years [35].

The results are summarized in Figs. (12a-12b) which demonstrate that the ${ }^{234} \mathrm{U} /{ }^{238} \mathrm{U},{ }^{230} \mathrm{Th} /{ }^{238} \mathrm{U}$, ${ }^{230} \mathrm{Th} /{ }^{234} \mathrm{U},{ }^{226} \mathrm{Ra} /{ }^{238} \mathrm{U}$ and ${ }^{226} \mathrm{Ra} /{ }^{230} \mathrm{Th}$ activity ratios for most of the studied samples deviate significantly from equilibrium. These activity ratios are consistent with the preferential mobilization of uranium from the studied samples by leaching process.

Table (3): The specific activity ratios of radionuclides in uranium series $\left({ }^{238} \mathrm{U}\right)$ and $\left.{ }^{235} \mathrm{U}\right)$

\begin{tabular}{|c|c|c|c|c|c|c|c|c|}
\hline \multirow{3}{*}{$\begin{array}{l}\text { Activity } \\
\text { ratios } \\
{ }^{238} U^{235} U\end{array}$} & \multicolumn{8}{|l|}{ Sample No. } \\
\hline & 1 & 2 & 3 & 4 & $3 \mathbf{N}$ & $4 N$ & $5 \mathrm{~N}$ & $6 \mathrm{~N}$ \\
\hline & $21.79 \pm 0.83$ & $21.82 \pm 1.18$ & $21.78 \pm 1.99$ & $21.65 \pm 1.24$ & $21.98 \pm 1.39$ & $21.78 \pm 1.12$ & $21.62 \pm 0.82$ & $21.80 \pm 1.57$ \\
\hline${ }^{234} \mathbf{U} /{ }^{235} \mathbf{U}$ & $20.26 \pm 0.76$ & $19.52 \pm 5.70$ & $20.37 \pm 11.79$ & $23.11 \pm 3.46$ & $21.74 \pm 5.70$ & $18.61 \pm 7.55$ & $19.01 \pm 3.69$ & $21.76 \pm 9.40$ \\
\hline${ }^{234} \mathbf{U} /{ }^{238} \mathbf{U}$ & $0.93 \pm 0.03$ & $0.89 \pm 0.26$ & $0.94 \pm 0.52$ & $1.07 \pm 0.14$ & $0.99 \pm 0.25$ & $0.85 \pm 0.33$ & $0.88 \pm 0.17$ & $1.00 \pm 0.42$ \\
\hline${ }^{226} \mathbf{R a}^{1238} \mathbf{U}$ & $0.88 \pm 0.02$ & $1.17 \pm 0.03$ & $0.96 \pm 0.04$ & $1.00 \pm 0.02$ & $0.97 \pm 0.03$ & $1.28 \pm 0.03$ & $1.17 \pm 0.02$ & $1.05 \pm 0.04$ \\
\hline${ }^{230} \mathrm{Th} /{ }^{238} \mathrm{U}$ & $0.78 \pm 0.03$ & $0.69 \pm 0.04$ & $1.14 \pm 0.09$ & $0.89 \pm 0.05$ & $0.40 \pm 0.03$ & $0.65 \pm 0.03$ & $0.62 \pm 0.03$ & $0.60 \pm 0.05$ \\
\hline${ }^{230} \mathrm{Th} /{ }^{234} \mathrm{U}$ & $0.83 \pm 0.04$ & $0.77 \pm 0.25$ & $1.22 \pm 0.75$ & $0.83 \pm 0.13$ & $0.40 \pm 0.21$ & $0.76 \pm 0.31$ & $0.71 \pm 0.16$ & $0.60 \pm 0.43$ \\
\hline${ }^{226} \mathrm{Ra} /{ }^{230} \mathrm{Th}$ & $1.14 \pm 0.03$ & $1.70 \pm 0.06$ & $0.85 \pm 0.04$ & $1.12 \pm 0.04$ & $2.45 \pm 0.16$ & $1.97 \pm 0.08$ & $1.88 \pm 0.06$ & $1.76 \pm 0.09$ \\
\hline${ }^{210} \mathrm{~Pb} /{ }^{226} \mathrm{Ra}$ & $0.50 \pm 0.004$ & $0.39 \pm 0.004$ & $0.45 \pm 0.007$ & $0.67 \pm 0.006$ & $0.23 \pm 0.004$ & $0.32 \pm 0.004$ & $0.33 \pm 0.003$ & $0.30 \pm 0.005$ \\
\hline${ }^{230} \mathrm{Th} /{ }^{234} \mathrm{Th}$ & 0.89 & 0.96 & 1.44 & 0.89 & 0.94 & 0.93 & 0.96 & 1.09 \\
\hline
\end{tabular}




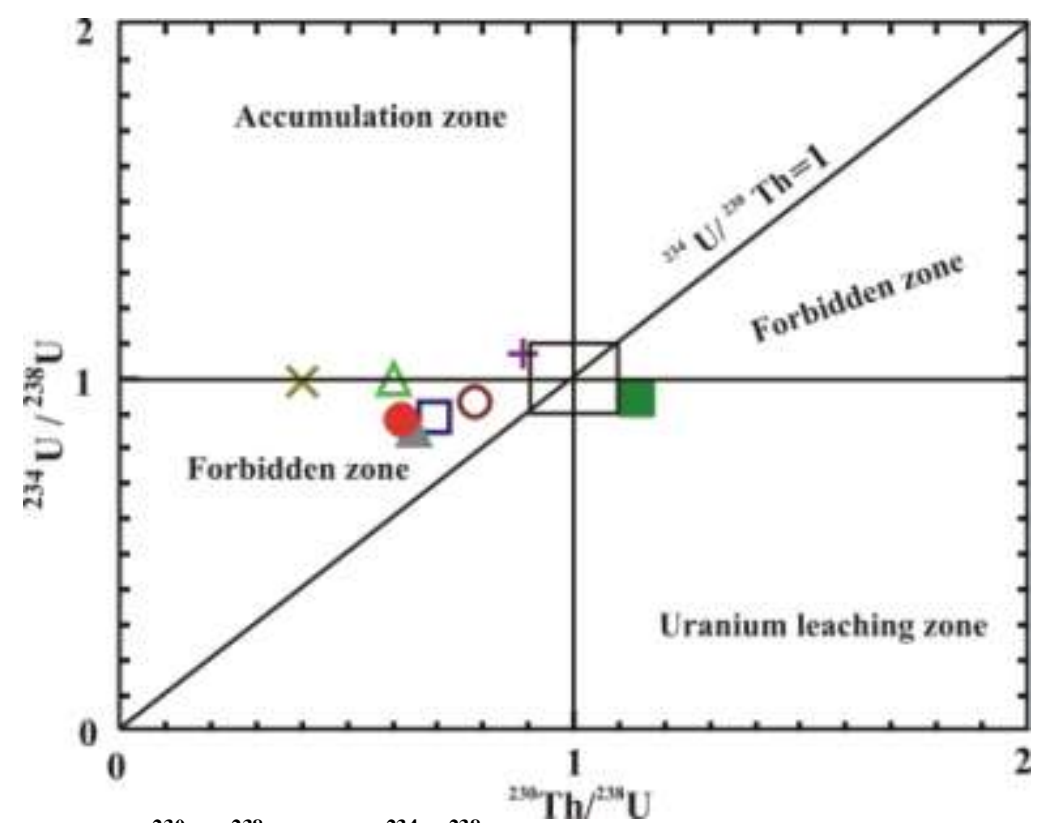

Figure (11): Thiel diagram of ${ }^{230} \mathrm{Th} /{ }^{238} \mathrm{U}$ versus ${ }^{234} \mathrm{U} /{ }^{238} \mathrm{U}$. Forbidden zones for any single process and the boxed area indicates the secular equilibrium condition. Symbols as Fig. (8a)

The ratio between ${ }^{230} \mathrm{Th} /{ }^{238} \mathrm{U}$ and ${ }^{230} \mathrm{Th} /{ }^{234} \mathrm{Th}$ is plotted in Fig. (12c) which demonstrates that the ${ }^{230} \mathrm{Th} /{ }^{238} \mathrm{U}$ activity ratios for all studied samples lower than unity deviate significantly from equilibrium. It is worth noting that the ${ }^{230} \mathrm{Th} /{ }^{234} \mathrm{Th}$ activity ratios for all studied samples are nearly close to unity and ranged from 0.89 to 0.96 except sample 3 which is greater than unity and equals 1.44. So, the relation between ${ }^{230} \mathrm{Th} /{ }^{234} \mathrm{Th}$ is more significant in equilibrium than ${ }^{230} \mathrm{Th} /{ }^{238} \mathrm{U}$ because ${ }^{230} \mathrm{Th}$ and ${ }^{234} \mathrm{Th}$ have similar behaviors in the chemical weathering of minerals.

Moreover, ${ }^{210} \mathrm{~Pb} /{ }^{226} \mathrm{Ra}$ ARs are lower than unity for all samples, whereas ARs of ${ }^{238} \mathrm{U} /{ }^{235} \mathrm{U}$ for all samples are ranging between 21.62 and 21.98 which reflect the natural ratio (21.7).

\section{Interpretation and Discussion}

The mineralization at the Zug El Bohar shear zone can be interpreted through combining field observations with existing minerals and concentrations of major and trace elements as well as ambient sedimentary rocks that hosted the shear zone. The sedimentary rocks that hosted the shear zone at the deposit were shaped by five major events, starting with clastic host-rock sedimentation, followed by the diagenesis, the Red Sea rifting which is accompanied by faults and volcanic activity, hydrothermal alteration and mineralization and supergene processes.
On the other hand, the basement rocks of the Red Sea coastal plain, which are found under the sedimentary sequence of the studied area underwent metamorphism, deformation and erosion before they were cut by faults and extruded new igneous rocks that accompanied the Red Sea rift. The hydrothermal alteration of the basement and sedimentary rocks, as well as the mineralization that were formed along the shear zone accompanied this stage.

The mineralized shear zone samples have been examined, and this indicated that the hematite and limonite are the main constituents besides clay minerals and calcium carbonate as well as celestite $\left(\mathrm{SrSO}_{4}\right)$ and manganese oxides. Moreover, uranium occurs in abnormal concentrations with no detected minerals, whereas minerals such as wulfenite, zaccagnaite, baileychlore, mimetite, calcian mimetite, arsenatian vanadinite and galena $(\mathrm{PbS})$ were recorded. These minerals are carrying, $\mathrm{Pb}, \mathrm{Mo}, \mathrm{Zn}, \mathrm{V}$ and As elements. Consequently, the shear zone deposits were formed under oxidation conditions, where oxidized deposits are defined as a type of deposits in which over $30 \%$ occur in combination with $\mathrm{O}_{2}$ as minerals of carbonates, oxides, beside sulphides [36]. The high celestite concentrations are controlled by lithostratigraphic and structural factors similar to the case with the Red Sea belt polymetallic mineralization [6]. 

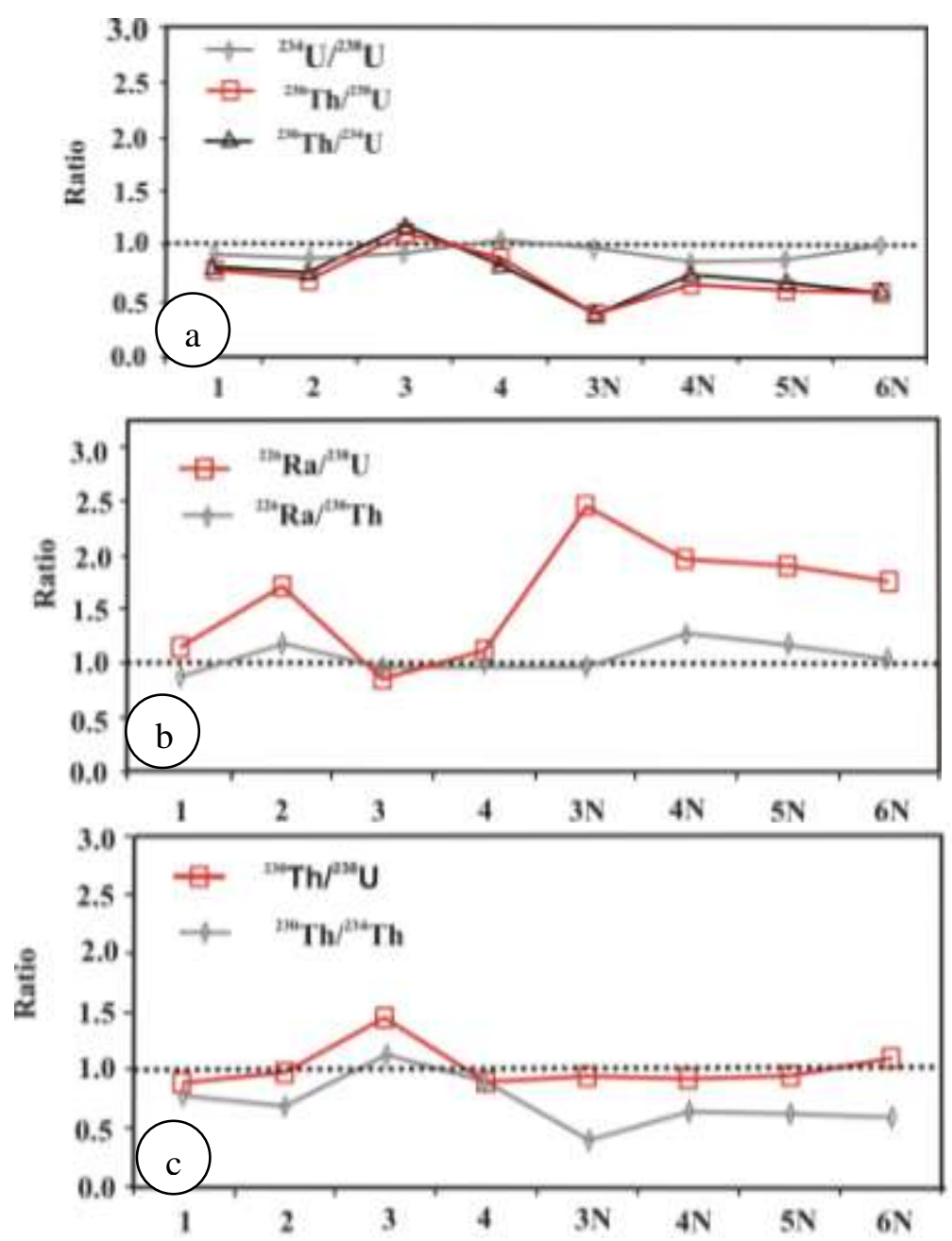

Figure (12): The activity ratio variations of the studied samples from the equilibrium state, $\mathrm{a}^{234} \mathrm{U} /{ }^{238} \mathrm{U},{ }^{230} \mathrm{Th} /{ }^{238} \mathrm{U}$ and ${ }^{230} \mathrm{Th} /{ }^{234} \mathrm{U}, \mathrm{b}-{ }^{226} \mathrm{Ra} /{ }^{238} \mathrm{U}$ and ${ }^{226} \mathrm{Ra} /{ }^{230} \mathrm{Th}$ and $\mathrm{c}^{230} \mathrm{Th} /{ }^{238} \mathrm{U}$ and ${ }^{230} \mathrm{Th} /{ }^{234} \mathrm{Th}$. Note, the equilibrium state (activity ratio $=1.00 \pm 0.1$ ) is shown with the dashed lines

Uranium, molybdenum, lead, zinc and arsenic deposits geochemical conditions (e.g., $\mathrm{pH}, \mathrm{Ca}^{2+}$, and $\mathrm{PCO}_{2}$ ) Uranium minerals were not recorded within the shear zone but the binary diagrams indicated that uranium is absorbed on Kaolin minerals, gibbsite and Mn oxides (Figs.8a-b), meanwhile the other clay minerals (e.g., chlorite) did not have any effect on uranium concentrations (Fig.8h). On the other hand, iron oxides have a weak effect on uranium concentrations (Fig. 8g). This fact is due to under oxic conditions, the hexavalent uranyl ion $\left(\mathrm{UO}_{2}{ }^{2+}\right)$ is a predominant complex in solutions at low $\mathrm{pH}$, but when $\mathrm{CaCO}_{3}$ is added to the shear solutions causing many hydrolysis and carbonate complexes are predominant at neutral to alkaline $\mathrm{pH}$ values [37]. The uranium (VI) aqueous species of carbonate complexes in the shear zone solutions are the $\mathrm{CaUO}_{2}\left(\mathrm{CO}_{3}\right)_{3}{ }^{2-}$ and $\mathrm{Ca}_{2} \mathrm{UO}_{2}\left(\mathrm{CO}_{3}\right)_{3}{ }^{0}$ (aq.) $[38,39]$. Additionally, uranium (VI) mobility in this shear is significantly slowed by an adsorption and/or a reduction, and strongly affected by the and their impacts on uranium (VI) aqueous speciation $[40,41]$. For instance, raising the partial pressure of $\mathrm{CO}_{2} \quad\left(\mathrm{PCO}_{2}\right)$ from the ambient limestone of the shear zone led to decrease the distribution coefficient $(K \mathrm{~d})$ value for uranium (VI) adsorption by ferrihydrite (Fig. 8g) by four orders of magnitude at $\mathrm{pH} 8$, as a result of the increasing importance of dissolved carbonate complexes [42]. The partial pressure of carbon dioxide is common in the shear zone solutions from an ambient limestone. Similarly, the $\mathrm{pH}$ and calcium concentration has been shown to have an impact on the distribution coefficient values [39]. Consequently, decrease the $\mathrm{U}$ (VI) sorption on ferrihydrite when the $\mathrm{CaUO}_{2} \quad\left(\mathrm{CO}_{3}\right)_{3}{ }^{2-}$ and $\mathrm{Ca}_{2} \mathrm{UO}_{2}\left(\mathrm{CO}_{3}\right)_{3}{ }^{0}$ (aq.) are predominant. On the other hand, the mobility of U(VI) in groundwater can be retarded by Mn oxides via strong adsorption (Fig.8b). The importance of adsorption of U(VI) to 
$\mathrm{Mn}$ oxides can be far greater than their relative abundance in sediments [43].

Additionally, the sulphide-bearing minerals (galena and celestite) in the shear zone became increasingly reduced with increasing $U$ concentrations (Fig. $8 \mathrm{c}$ ), where $\left(\mathrm{SO}_{4}\right)^{2-}$ was most likely added as sulfate in the oxidized fluid of the shear zone from ambient rocks and became reduced to sulfide through the interaction with positive complexes during mineralization [44].

Vanadium $\left[\mathrm{V}^{5+}\right]$ is the most common oxidation state in groundwater systems and forms anionic complexes with oxygen and hydroxide [45]. The distribution of vanadium in the shear zone correlates with the iron distribution (Fig. 13a). The solubility of metal vanadates, in particular, ferrous vanadate, may control the mobility of vanadium in groundwater systems (shear zone solutions), and vanadium has high solubility in alkaline solution [45]. Consequently $\mathrm{pH}$ and calcium concentration have been shown to have an impact on vanadate solubility values and decrease $\mathrm{V}(\mathrm{V})$ sorption on ferrihydrite when the $\mathrm{CaUO}_{2}\left(\mathrm{CO}_{3}\right)_{3}{ }^{2-}$ and $\mathrm{Ca}_{2} \mathrm{UO}_{2}$ $\left(\mathrm{CO}_{3}\right)_{3}{ }^{0}$ (aq) as are the predominant (Fig. 13a), so that there are drastically $\mathrm{V}$ increases that accompany the drastically Ca increases (Fig.13b), thus it has the same behavior of $\mathrm{Ca}$ concentrations with U (Fig. 8f).

The enrichment of molybdenum in the shear zone is driven by the solubility gradient of oxidized aqueous $\mathrm{Mo}^{6+}$ complexes as $\mathrm{U}^{6+}$, but there is a sharp increase in Mo concentration with the decrease in $U$ concentrations (Fig.8e). This relationship indicates that the effect of the other geochemical conditions as sulfate led to leaching of $U$ but at the same time led to precipitation of Mo minerals. Also, pH, $\mathrm{Ca}^{2+}$, and $\mathrm{PCO}_{2}$ show impacts on molybdenum (VI) aqueous speciation which is completely reversed uranium (Fig. 9a).
Finally, the presence of $\mathrm{OH}^{-}$and $\mathrm{Cl}^{-}$and $\mathrm{S}$ in minerals of $\mathrm{Pb}, \mathrm{Zn}$, As indicates that, these elements are found as hydroxide, chloride and Hydrosulfide complexes in hydrothermal solutions and their precipitation as minerals occur either by a drop in $\mathrm{pH}$ when $\mathrm{Ca}$ added to the solution (Figs.9ac).

\section{REE profiles}

The REE profiles of the shear zone samples show positive Gd anomalies which can be interpreted as follows: Gd is found always as in the trivalent and its fractionation is related to $\mathrm{Eu}$ and $\mathrm{Tb}$. It isn't affected by redox-related processes. Accordingly, Gd behavior, relative to neighboring elements, should be formed in response to some other intrinsic property for this element. The most possible explanation for this behavior may be the relatively stable electron configuration of $\mathrm{Gd}$, in which half of the outer $4 \mathrm{f}$ electron shell is filled (.e.g., tetrad effect [46]). Kim et al. [47] demonstrated the predominant factor controlling anomalous Gd behavior is alkalinity and carbonate complexation, in addition to, the higher particle reactivity of neighboring $\mathrm{Eu}$ and $\mathrm{Tb}$. Weak acidic solutions and those close to neutral $\mathrm{pH}$ values typically possess positive $\mathrm{Gd}$ anomalies, whereas alkaline solutions possess negative $\mathrm{Gd}$ anomalies. Accordingly, the studied samples were formed from solution is weakly acid to near neutral $\mathrm{pH}$. On the other hand, the behavior of Ce is contrary to that of Gd. It is a redox-sensitive in oxic nearneutral to slightly alkaline Earth surface systems. Bau and Koschinsky [48] reported that, after the initial surface complexation of $\mathrm{Ce}^{3+}$ on hydrogenetic $\mathrm{Fe}-\mathrm{Mn}$ crusts, the trivalent $\mathrm{Ce}$ is partially oxidized at the metal oxide or hydroxide (oxy) surface. Accordingly, Fe-Mnoxy hydroxides

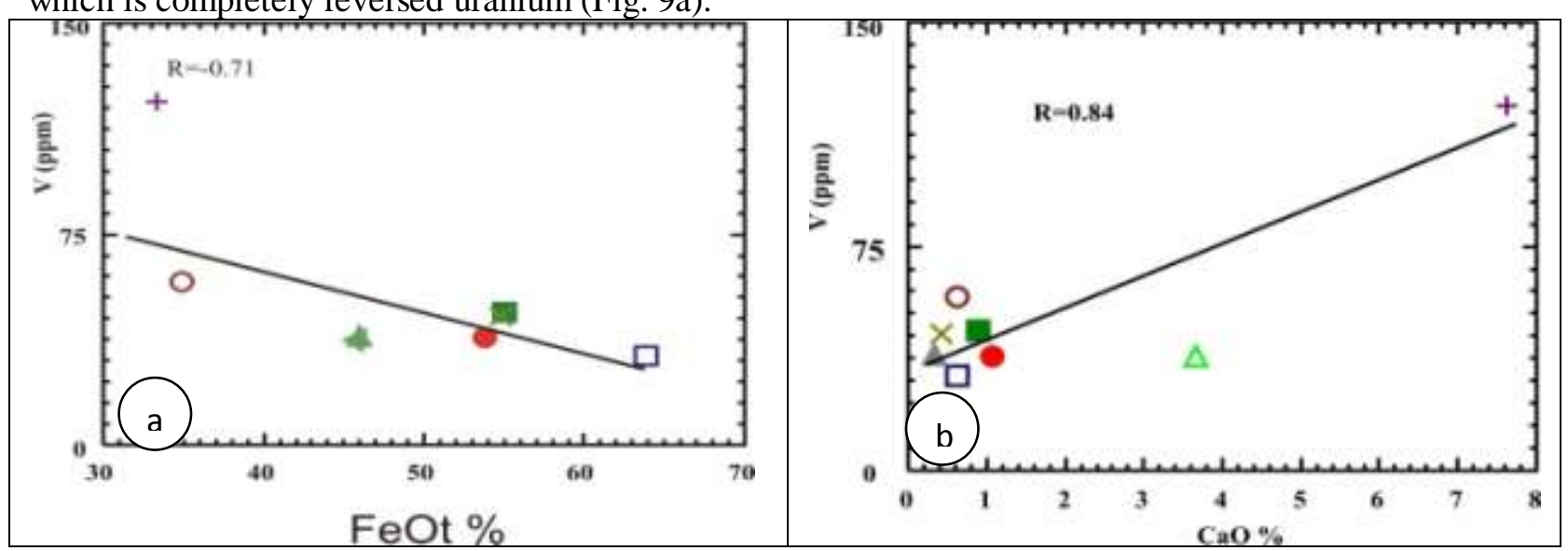

Figure (13): (a-b) Binary diagram of $\mathrm{V}$ versus $\mathrm{FeOt}$ and $\mathrm{CaO}$ respectively. Symbols as Figure (8a) 
had been found in the hydrothermal solutions led to the fraction and the scavenged $\mathrm{Ce}$ remains as $\mathrm{Ce}^{4+}$ at their solid's surface. With time, Fe-Mn oxyhydr oxides preferentially accumulate Ce over the other REE; results showed some samples with pronounced a positive $\mathrm{Ce}$ anomaly. In addition to all the above, the ionic radius of $\mathrm{Eu}^{2+}$ is larger than that of other REE (III) [49] and is more stable under high temperature and pressure but $\mathrm{Eu}^{3+}$ is more stable under low temperature and oxidation conditions [50]. REE transported mainly as chloride or fluoride complexes in most hightemperature hydrothermal fluids, but in lowtemperature fluids, they transported as mostly as $\mathrm{SO}_{4}{ }^{2-}$ complexes and free ions. The $\mathrm{SO}_{4}{ }^{2-}$ complexes could be ignored in high-temperature fluids, due to a low sulfate concentration. In Zug El Bohar fluids, the sulfate most likely originates from the oxidation of $\mathrm{H}_{2} \mathrm{~S}$ and $\mathrm{SO}_{2}$ gases that is found in the hydrothermal solution of magmatic origin and/or $\mathrm{SrSO}_{4}$ that coming from sedimentary rocks during the passing of fluids. The negative $\mathrm{Eu}$ anomaly is due to $\mathrm{Eu}^{2+}$ is oxidized to $\mathrm{Eu}^{3+}$ and the formation $\mathrm{EuSO}_{4}$ that is insoluble in solutions [51]. The previously large amount of sulfate that is found in Zug El Bohar fluids may scavenge $\mathrm{Eu}^{2+}$, thus preferential losses of Eu from solution relative to other REEs. Finally, the depletion of Tb is due to the REE bearing minerals were subjected to metasomatically alteration [52].

\section{The extreme enrichment in $U$ relative to $T h$}

The shear zone samples are extremely enriched by $\mathrm{U}$ relative to Th (Table 1) can be firstly attributed to uranium is comes from alkaline acidic rocks, where the low $\mathrm{Ca}$ granites (e.g. alkaline granites) may be enriched in Th relative to $U$ because some $\mathrm{U}$ enters into an aqueous phase as uranyl ions during the final stages of crystallization of granitic magmas [53]. However, Th remains locked into the lattice sites of granitic minerals crystallized from these magmas. The Second reason is the geochemical behavior of Th and U. Whereas $U$ is far more mobile because of its increased solubility at higher oxidation states and uranyl ions are moved in fractures and enhanced by the formation of complexes with carbonate and sulphate anions [54]. On the contrary, Th is less mobile than U due to the low solubility of thorium in most environments [55].

\section{Radioactive disequilibrium}

According to judging standards, activity ratios between 0.90 and 1.10 are referred to as secular equilibrium within the conservative (10\%) analytical error for the samples [56], consequently, the samples deviating from secular equilibrium, i.e., larger than 1.10 or less than 0.90 for ${ }^{234} \mathrm{U} /{ }^{238} \mathrm{U},{ }^{230} \mathrm{Th} /{ }^{238} \mathrm{U},{ }^{230} \mathrm{Th} /{ }^{234} \mathrm{U}$ and ${ }^{226} \mathrm{Ra} /{ }^{230} \mathrm{Th}$, with regarding the radionuclides behavior at the Zug El Bohar shear zone depend on respective chemical properties and the physicochemical characteristics of hydrothermal solutions and ambient sedimentary rocks. Previous studies of the Maderos river [57] showed that the concentration of free $\left(\mathrm{SO}_{4}\right)^{2-}$ and $\left(\mathrm{CO}_{3}\right)^{2-} /\left(\mathrm{HCO}_{3}\right)^{-}$in water can serve to indicate a more or less appropriate environment for the local retention of ${ }^{226} \mathrm{Ra}$ and uranium isotopes on the sediments. For example, a higher concentration of free sulfate in the water means a lower concentration of ${ }^{226} \mathrm{Ra}$. Thus, greater immobilization on the shear zone that cuts the sedimentary rocks, is probably by coprecipitation of ${ }^{226} \mathrm{Ra}$ with $\mathrm{SrSO}_{4}$. Similarly, higher concentrations of $\left(\mathrm{CO}_{3}\right)^{2-} /\left(\mathrm{HCO}_{3}\right)^{-}$can also enhance the retention of ${ }^{226} \mathrm{Ra}$ on the sediments, but at the same time improve markedly the mobilization of uranium via the formation of stable complexes that keep the uranium isotopes dissolved [58].

The activity ratios of ${ }^{234} \mathrm{U} /{ }^{238} \mathrm{U}$ and ${ }^{230} \mathrm{Th} /{ }^{234} \mathrm{U}$ (Table 3) for the shear zone samples plot out of the boxed area of the secular equilibrium. On the other hand, the activity ratios of secondary uranium concentrations are characterized by ${ }^{234} \mathrm{U} /{ }^{238} \mathrm{U}>1$ and ${ }^{230} \mathrm{Th} /{ }^{234} \mathrm{U}<1$ which is existed in sample 4 (Fig.11). This indicates the relatively recent precipitation of uranium from the supergene process with ${ }^{234} \mathrm{U} /{ }^{238} \mathrm{U}>1$. This result is similar to the cases studied by other authors $[59,32]$. Also, this diagram indicated a complex leaching and accumulation of uranium might take place for those samples $(1,2,4 \mathrm{~N}$ and $5 \mathrm{~N})$, where an initial uranium accumulation phase may have been followed by a relatively recent uranium leaching through the supergene process.

Moreover, ${ }^{226} \mathrm{Ra} /{ }^{230} \mathrm{Th}$ ARs are vary from 0.85 to 2.45. All samples are greater than unity except sample 3 which is a lower than unity. This could be due to a ${ }^{226} \mathrm{Ra}$ gain resulting from recoilimplanted ${ }^{226} \mathrm{Ra}$ atoms from the decay of ${ }^{230} \mathrm{Th}$ 
atoms and $\mathrm{Ra}$ readily adsorbed onto minerals formed in oxidized zones [60] or the shear zone hydrothermal solution is enriched by ${ }^{226} \mathrm{Ra}$ than ${ }^{230} \mathrm{Th}$ because the latter has previously been retained on the igneous source as a result of the low mobility. Also, one expects that radium is closely associated with calcium of limestone because of their chemical similarity.

Finally, ${ }^{210} \mathrm{~Pb} /{ }^{226} \mathrm{Ra}$ ARs are greater than unity for all samples, this may be due to the escaping of radon which is the daughter of ${ }^{226} \mathrm{Ra}$ and the parent for ${ }^{210} \mathrm{~Pb}$ or the local retention of ${ }^{226} \mathrm{Ra}$ in these samples as a result of the presence of $\left(\mathrm{SO}_{4}\right)^{2-}$ and $\left(\mathrm{CO}_{3}\right)^{2-} /\left(\mathrm{HCO}_{3}\right)^{-}$, consequently the ${ }^{226} \mathrm{Ra} /{ }^{210} \mathrm{~Pb}$ ARs are greater than unity for all samples of the shear zone.

\section{Conclusions}

1-The Zug El Bohar Shear zone has abnormal concentrations of $U$ as well as high concentrations of $\mathrm{Mo}, \mathrm{Pb}, \mathrm{Zn}$ and As.

2- These deposits were formed from a hot aqueous solution that was formed as a result of the mixture of groundwater and a hydrothermal solution. This solution was an oxidizing and a weak acid close to neutral $\mathrm{pH}$ values.

3- No uranium minerals were recorded, it is suggested that it could be found as elemental absorbed on kaolin, gibbsite and $\mathrm{MnO}$, but many minerals were detected to other associated elements.

4- The enrichment in $U$ and the depletion of Th in the shear zone samples can be attributed to many factors that caused the decoupling of $U$ and $T h$ concentrations such as the nature of the magmatic source and the behavior of $U$ and $T h$ in the hydrothermal and supergene processes.

5- The presence of $\mathrm{CaCO}_{3}$ in the hydrothermal solution from the surrounded rocks led to decrease $\mathrm{U}$ and $\mathrm{V}$ absorption on iron oxides, meanwhile led to increasing deposition of $\mathrm{Mo}, \mathrm{Pb}, \mathrm{Zn}$ and $\mathrm{As}$.

6- Both of $\mathrm{CaCO}_{3}$ and $\mathrm{SO}_{4}{ }^{2-}$ had the greatest influence on the REE patterns and radionuclides disequilibrium in the shear zone. Additionally, the groundwater circulation and other physicochemical conditions had affected on daughter/parent radionuclide activity ratios in the decay series, which led to their fractionation. Thus, the activity ratios were greater or less than unity.

\section{Recommendation}

Further studies are recommended to be performed on this area, because of the high anomalies of uranium and molybdenum.

\section{References}

1-Voodoo Skie, Quseir , Egypt. Retrieved 13 August (2013).

2-El-Anwar M.A.M., Geology of the area around Wadi Urn Gheig, Eastern Desert, Egypt. M.Sc. Thesis, Tanta University, (1983), 322p.

3-El-Shazly E.M., Controls of Tertiary ore deposition in Egypt. La Chronique des mines d'Outre-meret de la rechercheminière, No. 275, (1959), 139-146.

4-Gindy A.R., Radioactivity and Tertiary volcanic activity in Egypt; Econ. Geol., 56, (1961), 557-568.

5-El-Kholy S. B., Hashad A. H., Selim E.T.M., Lead isotopes and trace elements in some Miocene Red Sea galenas. Pure Applied and Geophysics, 81, (1970), 135-150.

6-EGS AMA / Sibai Party, On the result of prospecting work for rare and non-ferrous metals and gold in the area of wadies Um Gheig, Sitra, El Dabbah and Abu tundub conducted by Sibai party 4/73 during 19731974. EGSMA, Internal report.

7-Hassan M. M., Geochemical methods of prospecting for Lead-Zinc deposits in Eastern Desert of Egypt, Ph. D. Dissertation, Leningrad, Mining Institute, Leningrad, USSR, (1974), 150p.

8-Hassan M. M., 1990: Studies on lead zinc sulphide mineralization in the Red Sea coastal zone, Egypt: Proc. 8th Symp. IGADO, Otowa, Canada, (1990), 835-847.

9-Said, R., The geology of Egypt: New York, Elsevier, (1962), 377p.

10-Abbas H. L., A monograph on the Egyptian Cretaceous pelecypods, Egypt. Egyptian Geological survey Paleon. Ser. Mon.1, (1962), 22p.

11-El-Mohammady R. A., Ismail A. I. M., Gameel M., Mineralogical and Mechanical Compaction Characteristics of Nubian Sandstones, Gebel Duwi, Central Eastern Desert, Egypt. Middle East Journal of Applied Sciences, 4(4), (2014) 1016-1022.

12- Greene D. C., Structural geology of the Quseir area, Red Sea coast, Egypt: Contribution No. 52 (M.S. Thesis), Department of Geology and Geography, University of Massachusetts, Amherst (1984).

13-Issawi B., Francis M., El Hinnawi M., Mehanna A., Contribution to the structure and phosphate deposits of Quseir area. Egyptian Geological Survey, Paper No.50, (1969).

14-Issawi B., 1972: Review of upper Cretaceous-lower Tertiary stratigraphy in central and southern Egypt: American Association of Petroleum Geologist Bulletin, 56 (8), (1972), 1448-1463.

15-Johnson M. A., Stratigraphy and paleogeographic/paleotectonic history of the middle 
Miocene Gebel El Rusas Formation, Red Sea coast, Egypt: M.S. thesis, Univ. South Carolina, Columbia, (1977).

16-Kashkai M. A., The hydrothermal and hydrothermalmetasomatic formation of kaolin and a genetic classification of clay rocks. Academy of sciences, Baku Azerbaijan S.S. R., (1958), 47p

17-Stephens J. D., Tuddenham W. M, Infrared spectroscopy. In Modern methods of geochemical analysis, R. E. Wainerdi et al. (eds.), New York, (1971).

18-Richard and Cheryl Sittinger, Mineral of the month club 1770 Orville Avenue Cambria, Ca 93428, and www.mineralofthe monthclub.org (2009).

19-Kudrin A.V., Varyash L. N., Pashkov Yu. N., Rekharsky V. I., The geochemical behaviour of copper and molybdenum in ore-forming processes in geology and metallogeny of copper deposits (ed. by G. H. Friedrich et al.), Springer-Verlag Berlin Heidelberg, (1986).

20-Merlino Si, Orlandi P., Carraraite and zaccagnaite, two new minerals from the Carrara marble quarries: their chemical compositions, physical properties, and structural features. American Mineralogist, 86, (2001), 1293-1301.

21-Jacquat O., Voegelin A., Villard A., Marcus M. A., Kretzschmar R., Formation of Zn-rich phyllosilicates, Zn-layered double hydroxide and hydrozincite in contaminated calcareous soils. Geochimica et Cosmochimica Acta,, 72, (2008), 5034-5057.

22- Anthony J. W., Bideaux R.A., Bladh K. W., Nichols M.C., Handbook of Mineralogy, Volume IV. Arsenates, Phosphates, Vanadates. Mineral Data Publishing, Tucson, AZ, (2000), 680p.

23-Asadi S., Rajabzadeh M. A., Geochemistry, Paragenesis, and Wall-Rock Alteration of the Qatruyeh Iron Deposits, Southwest of Iran: Implications for a Hydrothermal-Metasomatic Genetic Model. Article ID 590540, (2014), 25 pages.

24-Abu-Deif A., Abouelnage S., Hassanein I., Distribution of radioelement and its relation to uranium migration, El-Erediya exploration tunnels, Central Eastern Desert, Egypt. Journal King Abdual Aziz University, Earth Science, 13 (2001), 19-40.

25-Aswathanaray U., Principle of nuclear geology.Oxonian Press Pvt. Ltd., New Delhi, (1985) 397p.

26-Taylor S. R., McClennan S. M., The Continental Crust: Its composition and evolution. Oxford, UK: Black well Scientific Publications, (1985), 312p.

27-Boynton W. V., Geochemistry of the rare earth elements: meteorite studies; in Rare Earth Element Geochemistry, P. Henderson (ed.), Elsevier, (1984), 63-114.

28-UNSCEAR, United Nations Scientific Committee on the Effects of Atomic Radiation, "Sources and Effects of Ionizing Radiation', Report to General
Assembly, with Scientific Annexes United Nations. United Nations, New York, (2000).

29-Osmond J., Ivanovich M., Uranium series mobilization and surface hydrology. In: Ivanovich, M., Harmon, R.S. (Eds.), Uranium-series Disequilibrium: Application to Earth, Marine, and Environmental Sciences, 2nd ed. Oxford Sciences Publications, Oxford, (1992), 259-289.

30-Brantley S., Kubicki J., White A., Kinetics of waterrock interaction. Springer Science? Business Media, LLC, New York (2008).

31-Thiel K., Vorwerk R., Saager R., Stupp H., ${ }^{235}$ Ufission tracks and ${ }^{238} \mathrm{U}$-series disequilibria as a means to study recent mobilization of uranium in Archaean pyretic conglomerates. Earth and Planetary Science Letter, 65, (1983), 249-262.

32-Osmond J., Dabous A., Dawood, Y., U-series age and origin of two secondary uranium deposits, central Eastern Desert, Egypt. Economic Geology, 94, (1999), 273-280.

33-Chabaux F., Riotte J., Dequincey O., Uranium-series geochemistry: U-Th-Ra fractionation during wea thering and river transport. Reviews in Mineralogy and geochemistry, 52, (2003), 533-576.

34-El Aassy I. E., El Galy M., Nada A., El Feky M., Abdel Maksoud T., Talaat S., Ibrahim E., Effect of alteration processes on the distribution of radionuclides in uraniferous sedimentary rocks and their environmental impact, Southwestern Sinai, Egypt. Journal of Radioanalytical Nuclear Chemistry, 289, (2011), 173-184.

35-Condomines M., Brouzes C., Rhis S., Radium and its daughters in hydrothermal carbonates from Auvergne (French Massif Central): origin and dating applications. C.R. Acad. Sci. Series IIA-Earth Planetary Sciences, 328, (1999), 23-28.

36-Cabala J., development of oxidation in $\mathrm{Pb}-\mathrm{Zn}$ deposits in Olkusz area, In; Mineral deposits at the beginning of the 21st Century, Balkema, (2001), 121124.

37-Waite T. D., Davis J. A., Payne T. E., Waychunas G. A., Xu N., Uranium (VI) adsorption to ferrihydrite; application of a surface complexation model. Geochimica et Cosmochimica Acta,, 58(24), (1994), 5465-5478.

38-Dong W. M., Brooks S. C., Determination of the formation constants of ternary complexes of uranyl and carbonate with alkaline earth metals $\left(\mathrm{Mg}^{2+}, \mathrm{Ca}^{2+}\right.$, $\mathrm{Sr}^{2+}$, and $\mathrm{Ba}^{2+}$ ) using anion exchange method. Environmental Science and Technology, 40 (2006), 4689-4695

39-Fox P. M., Davis J. A., ZacharaJ. M., The effect of calcium on aqueous uranium (VI) speciation and adsorption to ferrihydrite and quartz. Geochimica et Cosmochimica Acta, 70, (2006)1379-387.

40-Davis J. A., Meece D. E., Kohler M. G. P. Curtis G. P., Approaches to surface omplexation modeling of uranium (VI) adsorption on aquifer sediments, 
Geochimica et Cosmochimica Acta, 68(18), (2004), 3621-3641.

41-Jeon B. H., Dempsey B. A., Burgos W. D., Barnett M. O., Roden E. E., Chemical reduction of U(VI) by $\mathrm{Fe}(\mathrm{II})$ at the solid-water interface using natural and synthetic Fe(III) oxides, Environmental Science and Technology, 39, (2005), 5642-5649.

42-Curtis G.P., Davis J.A., Kohler M., Comparing approaches for simulating the reactive transport of $\mathrm{U}(\mathrm{VI})$ in ground water. Mine Water and the Environment, 28, (2009) 84-93.

43-Wang Z., Lee S. W., Catalano J. G., LezamaPacheco S. J., Bargar J. R., Tebo B. M., Giammar D. E., Adsorption of Uranium (VI) to Manganese Oxides: X-ray Absorption Spectroscopy and Surface Complexation Modeling. Environment Science and Technology, 47, (2013), 850-858.

44-Hurtig N. C., Heinrich C. A., driesner T., Herrmann W., Fluid Evolution and Uranium (-Mo-F) Mineralization at the Maureen Deposit (Queensland, Australia): Unconformity-related hydrothermal ore formation with a source in the volcanic cover sequence. Economic Geology, 109, (2014), 737-773.

45-Hem J. D., Study and Interpretation of the Chemical Characteristics of Natural Water, 3rd Edition, U.S. Geol. Surv. Water Supply Paper 2254, (1985).

46-Bau M., Scavenging of dissolved yttrium and rare earths by precipitating iron xyhydroxide: experimental evidence for $\mathrm{Ce}$ oxidation, $\mathrm{Y}-\mathrm{Ho}$ fractionation, and lanthanide tetrad effect. Geochimica et Cosmochimica Acta, 63, (1999), 6777.

47-Kim K. H., Byrne R. H., Lee, J. H., Gadolinium behavior in seawater: A molecular-basis for gadolinium anomalies. Marine Chemistry, 36(1-4), (1991), 107-120.

48-Bau M., Koschinsky A., Oxidative scavenging of cerium on hydrous Fe oxide: evidence from the distribution of rare earth elements and yttrium between Fe oxides and $\mathrm{Mn}$ oxides in hydrogenetic ferromanganese crusts. Geochemical Journal, 43, (2009) 37-47.

49-Shannon R. D., Revised effective ionic radii and systematics studies of interatomic distances in halides and chalcogenides. Acta Crystallographica, A32, (1976), 751-767.

50-Bau M., Rare-earth element mobility during hydrothermal and metamorphic fluid-rock interaction and the significance of the oxidation state of europium. Chemical Geology, 93,(1991) 219-230.

51-Handbook of Chemistry and Physics, Internet Version 2007, (87th Edition), David R. Lide, ed., Taylor and Francis, Boca Raton, FL. (2007).

52-Distler V.V., Yudovskaya M.A., Genetic model of the black shale hosted PGE-gold, Sukhi Log deposit, Russia. In: Piestrzynski et al (eds), Mineral deposits at the Beginning of the 21st Century, (2001), 47-50.
53-Attendorn H.G., Bowen R. N. C., Radioactive and stable isotope geology, 1st Edition, Chapman \& Hall, London, (1997), 87p

54-Bowden P., Herd D., Kinnaird J. A., The significance of Uranium and Thorium concentrations in pegmatitic leucogranites (alaskites), Rössing Mine, Swakopmund, Namibia. Communications of the Geological Survey of Namibia, 10, (1995) 43-49.

55-Lidman F., Morth C. M., Laudo H., Landscape control of uranium and thorium in boreal streams spatiotemporal variability and the role of wetlands. Biogeosciences, 9, (2013), 4773-4785.

56-Min M., Peng X., Wang J. Osmond J., Uranium series disequilibria as a means to study recent migrationof uranium in sandstone-hosted uranium deposit, NWChina. Applied Radiation and Isotopes, 63, (2005), 115-125.

57-Lozano J.C., Vera Tome’ F., Go'mez Escobar V., Blanco Rodri'guez P., Radiological characterization of a uranium mine with no mining activity. Applied Radiation and Isotopes 53, (2000), 337-343.

58-Lozano J.C., Blanco P. R., Vera Tome' F., Distribution of long-lived radionuclides of ${ }^{238} \mathrm{U}$ series in the sediments of a small river in uranium mineralized region of Spain. Journal of Environmental Radioactivity, 63, (2002), 153-171

59-Levinson A., Bland C., Dean J., Uranium series disequilibrium in young surficial uranium deposits in southern British Columbia. Canadian Journal of Earth Sciences, 21, (1984), 559-566.

60-Ibrahim E., Sayed F., Mohamed G., Research article U-series radionuclides disequilibria as indication of recent mobilization in the metamorphosed sandstone, Wadi Sikait, South Eastern Desert, Egypt. International Journal of Recent Scientific Research, 7(2), (2016), 8849-8858. 